2. REVIEW CRITERIA.

3. FORT ST. VRAIN UPGRADED TECFNICAL SPECIFICATIONS, FSAR, SER, APPENDIX A TO FACILITY OPERATING LICENSE DPR-34 (ORIGINAL TECHNICAL SPECIFICATIONS), AND LICENSING AMENDMENTS TO FACILITY OPERATING LICENSE DPR-34 CONSISTENCY COMPARISON.

3.1 Safety Limits and Limiting Safety System Settings (FSV UT/S Section 2.0)

3.2 Reactivity Control System: (FSV UT/S Section 3/4.1)

3.3 Safe Shutdown Cooling Systems (FSV UT/S Section 3/4.5)

3.4 PCRV and Confinement Systems (FSV UT/S Section 3/4.6).

3.5 Auxiliary Electric Power Systems (FSV UT/S Section 3/4.8)

4. SUMMARY AND CONCLUSION

5. REFERENCES

\title{
DISCLAIMER
}

This report was prepared as an account of work sponsored by an ageney of the United States Government. Neither the United States Government nor any agency thereof, nor any of their employees. makes any warranty, express or implied, of assumes any legal liability or responsi. bjlity for the accuracy, completeness, or usefulness of any information, apparatus, product, or process disclosed, or represents that its use would not infringe privately owned rights. Reference herein to any specific commercial product, process, or serviø by trade name, 1rademark. manufacturet. o: otherwise does not necessarily constitute or imply its endorsement, recommendation, or favoring by the United States Government or any agency theroof. The views and opinsons of authors expressed herein do not necessarily state or reflect those of the United Stutes Government or any agency thc:eof. 
APPENDICES

A.1 APPENDIX A TO FACILITY OPERATING LICENSE DPR-34 (OLD TECHNICAL SPECIFICATIONS) TABLE OF CONTENTS AS AMENDED TO AMENDMENT $60(6 / 20 / 88)$, WITH CROSS REFERENCE TO FORT ST. VRAIN UPGRADED TECHNICAL SPECIFICATIONS SECTIONS

A.2 FINAL DRAFT FORT ST. VRAIN UPGRADED TECHNICAL SPECIFICATIONS TABLE OF CONTENTS WITH CROSS REFERENCE TO APPENDDX A TO FACILITY OPERATING LICENSE DPR-34 (OLD TECHNICAL SPECIFICATIONS) AS AMENDED TO AMENDMENT $60(6 / 20 / 88)$

A.3 FORT ST. VRAIN AMENDMENTS TO FACILITY OPERATING LICENSE DPR-34 WITH CROSS REFERENCE TO PREVIOUS AND UPGRADED FORT ST. VRAIN TECHNICAL SPECIFICATIONS SECTIONS.

A.4 ACRONYMS USED IN TECHNICAL EVALUATION REPORT OF FORT ST. VRAIN FINAL DRAFT UPGRADED TECHINICAL SPECIFICATIONS 


\section{TECHNICAL EVALUATION REPORT OF THE FORT ST. VRAIN FINAL DRAFT UPGRADED TECHNICAL SPECIFICATIONS}

\section{INTRODUCTION}

The Fort St. Vrain Nuclear Generating Station is a High Temperature Gas-cooled Reactor (HTGR) designed and built by the General Atomic Company to operate at 842 MWth and 330 MWe. Application for construction of the Fort St. Vrain plant was docketed (Docket No. 50-267) with the Atomic Energy Commission (now the Nuclear Regulatory Commission or NRC) on October 20, 1966. Construction of the plant was authorized on September 17, 1968 with issuance of Construction Permit, CPPR-54, to the applicant, Public Service of Colorado (PSC). The Facility Operating License, DPR-34, was issued to PSC on December 12, 1973 with first criticality achieved on January 1, 1974. First electricity was generated on December 11, 1976 and commescial operation declared on July 1, 1979.

On June 23, 1984, following a scram signal at the Fort St. Vrain plant, 6 of 37 pairs of control rods failed to insert. The NRC staff had also noted for several years, a decline in the licensee's performance in plant operations. Following this event, an assessment of the overall operation of the Fort St. Vrain plant was ordered by the NRC Office of Nuclear Reactor Regulation (NRR). One of the recommendations of the NRC/NRR assessment of the Fort St. Vrain operations was an upgrading of the Fort St. Vrain Technical Specifications.

This report is a technical evaluation of the final draft of the Fort St. Vrain (FSV) Upgraded Technical Specifications (UT/S) as issued by Public Service of Colorado (PSC) on May 27, 1988 with subsequent supplemental updates issued on June 15, 1988 and August 5, 1988. It has been compared for consistency, and safety conservatism with the Fort St. Vrain (FSV) Updated Final Safety Analysis Report (FSAR), the FSV Safety Evaluation Report (SER), the Facility Operating License, DPR-34, and all amendments to the Facility Operating License issued as of June 1, 1988, and Appendix A to the Operating License DPR-34, Technical Specifications. Because of the age of the plant, no supplements to the Fort St. Vrain SER have been issued since the original SER was not issued as a WASH or a NUREG report. This made it necessary to review all amendments to the Facility Operating License since 
they would contain the safety evaluations done to support changes to the Facility Operating License. The upgraded Fort St. Vrain Technical Specifications were also broadly compared with the latest Westinghouse Standard Technical Specifications (WSTS) to assure that what was proposed for Fort St. Vrain was consistent with the latest NRC staff practices for standard technical specifications.

The specific sections of the Fort St. Vrain Upgraded Technical Specifications audited by the Lawrence Livermore National Laboratory (LLNL) were selected in conjunction with the NRC/NRR staff for their safety significance. These sections are listed in Section 2 of this report. The criteria used to evaluate these sections are also presented in Section 2.

Discussion and evaluation of the audited sections of the Fort St. Vrain Upgraded Technical Specifications are presented in Section 3 of this report. A summary of the findings of this audit are presented in Section 4. Section 5 lists references used in this report. Appendices are included as aids and cross references between the various documents covered in this report.

\section{REVIEW CRJTERIA}

The following sections of the final draft of the Fort St. Vrain Upgraded Technical Specifications were audited by LLNL:

1. Safety Limits and Limiting Safety System Settings (Section 2),

2. Reactivity Control Systems (Section 3/4.1),

3. Safety Shutdown Cooling Systems (Section 3/4.5),

4. PCRV and Confinement Systems (Section 3/4.6), and

5. Auxiliary Electric Power Systems (Section 3/4.8.1).

Not all of the subsections contained within these sections were audited. Certain parts, particularly those subsections that apply when the Calculated Bulk Core Temperature (CBCT) is less than $760^{\circ} \mathrm{F}$, were not audited because of their lesser safety significance. 
The above listed sections of the final draft of the Fort St. Vrain (FSV) Upgraded Technical Specifications (UT/S) were audited by LLNL for consistency and safety conservatism with respect to the Fort St. Vrain (FSV) Updated Final Safety Analysis Report (FSAR), the original Fort St. Vrain (FSV) Safety Evaluation Report (SER), the Facility Operating License, DPR-34, and all amendments to the Faciiity Operating License issued as of June 20, 1988 (Amendments 1 to 60), and Appendix A (Technical Specifications) to the Facility Operating License. No supplements to the SER were included because the original SER was issued on January 20, 1972, before SERs were issued as WASH or NUREG reports. Safety evaluations were included as part of the amendments issued to the Facility Operating License which necessitated the inclusion of all amendments to the Facility Operating License as part of this audit. In addition, the Fort St. Vrain Upgraded Technical Specifications (UT/S) were broadly compared with the latest Westinghouse Standard Technical Specifications (WSTS) to assure that what was proposed for Fort St. Vrain was consistent with the latest NRC staff practices for standard technical specifications. It should be noted that only a broad comparison was made. A strict comparison was not possible because of the large difference in plant design between Fort St. Vrain (HTGR) and the standard Westinghouse PWR.

Each of the above listed sections were audited to determine if the Fort St. Vrain Upgraded Technical Specifications (hereafter referred as UT/S) were CONSISTENT, CONSERVATIVE or DIFFERENT than the documents they were compared to. A UT/S section was considered CONSISTENT if all the requirements, surveillances, and conditions were the same as that indicated in the reference documents. A UT/S section was considered CONSERVATIVE if most of the requirements, surveillances, and conditions, while differing from the reference documents, was supported by other documents which demonstrated that the changes could be considered conservative in so far as safety was concerned. A UT/S section was considered DiFFERENT if an important requirement, surveillance or condition was sufficiently different from the reference document, and was not supported by other documents which could demonstrated that the difference could be considered conservative in so far as safety was concerned. A difference was considered RESOLVED if additional requirements were added that reconciled the differences between the reference documents and the UT/S section, or if additional explanation was added to the bases which justified the difference, or if explanation 
was found in the Technical Evaluation Reports which justified the difference, or if reference was made to changes to the Fort St. Vrain FSAR which supported the changes. These definitions should not be considered "hard-and-fast" rules but only as general guidance. Considerable engineering judgment had to be exercised in auditing these sections.

3. FORT ST, VRAIN UPGRADED TECHNICAL SPECIFICATIONS, FSAR, SER, APPENDIX A TO FACILITY OPERATING LICENSE DPR-34 (ORIGINAL TECHNICAL SPECIFICATIONS), AND LICENSING AMENDMENTS TO OPERATING LICENSE DPR-34 CONSISTENCY COMPARISON

\subsection{Safety Limits and Limiting Safety System Settings (FSV UT/S Section 2.0)}

DISCUSSION. The requirements of the Reactor Core Safety Limits (Section 2.1.1 in the FSV UT/S) and the accompanying Power-to-Flow Ratio Limits (Section 3/4.2.6 in FSV UT/S) were formerly contained in Section 3.1 in the FSV T/S.

These requirements were amended by Amendment 23 to DPR-34, issued 3/16/81. Accompanying this amendment was the NRC staff SER which found the changes to the safety limits acceptable.

The specifications and limits in the old FSV T/S are supported by documentation provided by FSAR Sections 3.6.7.6.3, and 3.6.8. Additionally, Figures 3.2.6-1 and 3.2.6-2 of the FSV UT/S are the same as Figures 3.1-2 and 3.1-1 of the old FSV T/S and Figures 3.6.11 and 3.6.12 of the FSV FSAR, respectively.

No changes in current requirements and limitations were found. The old FSV T/S safety limit section for the Reactor Core lacked action statements so action statements were added in the FSV UT/S to provide additional guidance should a limit be exceeded. The action statements agreed with the accompanying bases for both Sections 2.1.1 and 3/4.2.6 of the UT/S and Section 3.1 of the old FSV T/S. The surveillance requirements added in Section 3/4.2.6 of the UT/S agreed with the 
accompanying bases for both Sections 2.1.1 and 3/4.2.6 of the UT/S and Section 3.1 of the old FSV T/S.

EVALUATION. This section is CONSISTENT.

\subsubsection{Reactor Vessel Pressure (FSV UT/S Section 2.1.2)}

DISCUSSION. The requirements of the Reactor Vessel Pressure Limits (Section 2.1.2 in the FSV UT/S) were formerly contained in Section 3.2 in the FSV $T / S$.

No amendments to these requirements were issued.

The specifications and limits are supported by documentation provided by FSAR Section 5.2 .

INo changes in current requirements and limitations were found. The old FSV T/S safety limit section for the Reactor Vessel Pressure lacked action statements so action statements were added in the FSV UT/S to provide additional guidance should a limit be exceeded. The action statements agreed with the accompanying bases for Section 2.1.2 of the UT/S and Section 3.2 of the old FSV T/S. Surveillance requirements were not part of either Section 2.1 .2 of the UT/S or Section 3.2 of the o!d FSV T/S.

EVALUATION. This section is CONSISTENT.

\subsubsection{Limiting Safety System Settings Trip Setpoints (FSV UT/S Section 2.2.1)}

DISCUSSION. The requirements of the Limiting Safety System Settings Trip Setpoints were formerly contained in Section 3.3 in the FSV T/S.

The specifications and limits are supported by documentation provided by FSAR Section 14.2. 
The old FSV T/S limiting safety system setting trip setpoints lacked action statements so action statements were added in the FSV UT/S to provide additional guidance should a limit be exceeded. Surveillance requirements were not part of either Section 2.2.1 of the UT/S or Section 3.3 in the old FSV T/S.

Amendment 60 to DPR-34 (issued 6/20/88) revised certain setpoints for the Plant Protective System (PPS) to allow for instrumentation error. These changes were reviewed by the Idaho National Engineering Laboratory (INEL) for the NRC and found to be acceptable.

\section{EVALUATION. This section is CONSISTENT.}

\subsection{Reactivity Control Systems (FSV UT/S Section 3/4.1)}

\subsubsection{Shutdown Margin (FSV UT/S Section 3/4.1.3)}

DISCUSSION. The requirements of the Shutdown Margin (Section 3/4.1.3 of the FSV UT/S) were formerly contained in Sections 4.1.2 and 4.1.8 (LCO) and 5.1.4 of the Old FSV T/S.

As originally stated, Sections 4.1.8 and 5.1.4 of the Old FSV T/S required that the reactor be shut down if expected reactivity deviates from the observed reactivity by a difference of 0.012 delta $\mathrm{k}$. In addition, it was not clear whether renormalization of base reactivity could be done at some point in the fuel cycle, thus obscuring the observed difference.

Amendment 13 to DPR-34 (issued 6/18/76) amended Sections 4.1.8 and 5.1.4 by adding a requirement that any difference of 0.01 delta $\mathrm{k}$ between predicted and observed reactivities, based on normalization to a base steady core condition, will require shutdown until a satisfactory explanation for the difference is found and permission to restart is received from PSC's Nuclear Facility Safety Committee (NFSC) to resume operations. Any renormalization of this base steady core condition as approved by the NFSC, was to be reported immediately to the NRC. 
Amendment 33 to DPR-34 (issued 3/8/83) reprinted Section 5.1.4 of the Old FSV T/S under the new page and section numbering system, but did not change any requirements. Therefore, no safety evaluation was performed.

The requirements specified in FSV UT/S 3/4.1.3 are essentially the same as the requirements formerly contained in Old FSV T/S 4.1.2, 4.1.8 and 5.1.4. The requirements in FSV UT/S 3/4.1.3 have added and made more explicit, the actions to be taken when the LCO cannot be met, and have also provided additional guidance in determining the Shutdown Margin under each operational mode defined for FSV.

However, the requirement for PSC's NFSC to give permission before any restart is attempted at FSV after an observed anomaly of 0.01 delta $\mathrm{k}$ between predicted and observed reactivities, has been moved to the Administrative Control Section 6.5.2.9b of the FSV UT/S. In addition, this same section also requires that any changes to the calculated base reactivity curve for use with each cycle as well as any changes to this data, including the justification of the change during the cycle must be approved by PSC s NFSC. This is acceptable, but since this requirement was part of the ICO in the Old FSV T/S, this should be retained as part of the LCO, or alternatively, a reference to Section $6.5 .2 .9 \mathrm{~b}$ of the FSV UT/S should be added somewhere to $3 / 4.1 .3$ of the FSV UT/S. A paragraph similar to a paragraph in the Bases to FSV UT/S 3/4.1.7 which could state that the any changes to the calculated base reactivity curve for use with each cycle as well as any changes to this data, including the justification of the change during the cycle will be approved by the NFSC. This paragraph could be added to the Beses of 3/4.1.4.1 of the FSV UT/S.

EVALUATION. This section is CONSISTENT. However, a requirement for PSC's NFSC to give permission before any restart is attempted at FSV after an observed anomaly of 0.01 delta $k$ between predicted and observed reactivities should be retained as part cf the LCO, or alternatively, a reference to Seciton 6.5.2. $\mathrm{b}$ of the FSV UT/S should be added to 3/4.1.3. This has been RESOLVED with the adrition of a reference to Section 6.5.2.9b to the Bases to 3/4.1.3. 


\subsubsection{Control Rod Pair Position and Worth Requirements-Operating}

(FSV UT/S Section 3/4.1.4.1)

DISCUSSION. The requirements of the control rod pair position and worth requirements at the operating (power, low power, and startup) operational modes (Section 3/4.1.4.1 of the FSV UT/S) were formerly contained in the Old FSV T/S Sections 4.1.3, 4.1.4 (LCOs) and 5.1.5 (SR).

A.mendment 4 to DPR-34 (issued 11/12/74) revised the basis for specification 4.1.3 (Old FSV T/S LCO) by changing the formula for determining the calculated average peaking factor for any refueling region, the calculated maximum intraregion power peaking factor for any refueling region, and the calculated axial peaking factor in any refueling region. The SER written by the AEC staff supporting the changes granted by Amendment 4 stated that these changes were made necessary by more extensive calculations recently performed that indicated that the limits calculated earlier should be modified.

Amendment 33 to DPR-34 (issued 3/8/83) reprinted Section 5.1.5 of the Old FSV T/S under the new page and section numbering system, but did not change any requirements. Therefore, no safety evaluation was performed.

The requirements specified in FSV UT/S 3/4.1.4.1 are essentially the same as the requirements formerly contained in Old FSV T/S 4.1.3, 4.1.4 and 5.1.5. The requirements in FSV UT/S 3/4.1.4.1 have added and made more explicit, the actions to be taken when the LCO cannot be met, and have also provided more explicit specifications for control rod pair position and worth rerlivements tor FSV's Power, Low Power and Startup operational modes.

However, the requirement for PSC's NFSC to approve the costrol rod withdrawal sequence, has been moved to the Administrative Contro! Section 6.5.2.9a of the FSV UT/S. This is acceptable, but since this requirement was part of the LCO in the Old FSV T/S, this should be retained as part of the LCO, or alternatively, a reference to Section 6.5.2.9a of the FSV Ur/S should be added somewhere to 3/4.1.4.1 of the FSV UT/S. A paragraph similar to a paragrapt in the Bases to FSV UT/S 3/4.1.7 could state that the control rod sequence will be approved 
by the NFSC prior to startup for each fuel cycle. This paragraph could be added to the Bases of 3/4.1.4.1 of the FSV UT/S.

One other question arose as to a difference between FSV UT,'S 3/4.1.4.1 and Old FSV T/S 4.i.4. Section 4.1.4 of the Old FSV T/S allowed 2 groups of 3 rod-pairs (6 rod-pairs) in addition to the regulating rod-pair to be partially inserted, "provided the two groups axial positions are separated by at least 10 feet." The phrase within the quotation marks was not retained in the FSV UT/S 3/4.1.4.1. No explanation could found in either the Old FSV T/S Bases to 4.1 .4 or in the Bases to FSV UT/S 3/4.1.4.1. Additional explanation is needed to justify the deletion of the phrase in quotation.

EVALUATION. This section is CONSISTENT. However, a requirement for PSC's NFSC to approve the control rod withdrawal sequence should be retained as part of the LCO, or alternatively, a reference to Section 6.5.2.9. If the FSV UT/S should be added to 3/4.1.4.1. In addition, explanation should be provided to justify the deletion of a phrase in Gid FSV T/S Section 4.1.4 from FSV UT/S 3/4.1.4.1. This has been RESOLVED with the addition of a reference to Section $6.5 .2 .9 \mathrm{~b}$ to the Bases to 3/4.1.4.1.

3.2.3 St.ztrol Rod Pair Position Requirements-Shutdown (FSV UT/S Section 3/4.1.4.2)

DISCIJSSION. The requirements of the control rod pair position and worth requirements at the shutdown (shutdown and refueling) operational modes (Section 3/4.1.4.2 of the FSV UT/S) were formerly contained in the Old FSV T/S Sections 4.1.3, 4.1.4 (LCOs) and 5.1.5 (SR).

Amenciment 4 to DPR-34 (issued 11/12/74) revised the basis for Section 4.1.3 (Old FSV T/S LCO) by changing the form:la for dete:...i.ing the calculated average peaking factor for any refueling region, the calculated ma. ' $1 \mathrm{~m}$ intra-region power peaking factor for any refueling region, and the caiculated axial peaking factor in any refueling region. The SER written by the AEC staf! supporting the changes granted by Amendment 4 stated that these changes were made necessary by more extersive 
calculations recently performed that indicated that the limits calculated earlier should be modified.

Amendment 33 to DPR-34 (issued 3/8/83) reprinted Section 5.1.5 of the Old FSV T/S under the new page and section numbering system, but did not change any requirements. Therefore, no safety evaluation was performed.

The Limiting Condition for Operations in FSV UT/S 3/4.1.4.2 are generally consistent with the Old FSV T/S Sections 4.1.3, 4.1.4, and 5.1.5. Since the Old FSV $\mathrm{T} / \mathrm{S}$ Sections 4.1.3, 4.1.4, and 5.1.5 did not explicitly specify requirements during the shutdown operating modes (since operational modes for FSV were not previously defined), a direct requirement-by-requirement comparison cannot be made. Essentially, the requirements in FSV UT/S 3/4.1.4.2 have added and made more explicit, the actions to be taken when the LCO cannot be met, and have also provided more explicit surveillance requirements for control rod pair position and worth requirements for FSV's Shutdown and Refueling operational modes.

EVALUATION. This section is CONSISTENT.

\subsubsection{Reactivity Changes witi Temperature (FSV UT/S Section 3/4.1.5)}

DISCUSSION. The requirements on the Reactivity Changes with Temperature (Section $3 / 4.1 .5$ of the FSV UT/S) were formerly contained in Section 4.1.5 (LCO) and 5.1.3 (SR) of the Old FSV T/S.

Amendment 33 (issued 3/8/83) reprinted Section 5.1.3 of the Old FSV T/S under the new page and section numbering system, but did not change any requirements. Therefore, no safety etraluation was performed.

The limits specified by FSV U/TS Section 3/4.1.5 are supported by FSV FSAR Section 3.5.5.1.

The limits, applicability, action and surveillance requirements of FSV UT/S 3/4.1.5 are consistent with the Old FSV T/S Sections 4.1.5 and 5.1.3. The surveillance requirement for FSV UT/S 3/4.1.5 specifies that the reactivity change as a function 
of core average temperature change be measured and integrated to verify that the measured reactivity change is within the limiting condition for operation at the beginning of each refueling cycle. This implies that this surveillance can be done while the FSV is in the power, low power and startup operating mode and not necessarily in the refueling mode. The surveillance intervals for measuring the reactivity temperature coefficient seemed to be inconsistent with the surveillance interval for Westinghouse PWRs which specifies after each fuel loading and within 7 effective full power days (EFPD) after reaching an equilibrium boron concentration of $300 \mathrm{ppm}$ at any thermal power. The surveillance interval at FSV for measuring the reactivity temperature coefficient as a function of core average temperature change at only the beginning of each refueling cycle is acceptable because FSV's reactivity temperature coefficient is not dependent on the density of its moderator (FSV has a solid graphite moderator) or on the soluble boron concentration in its primary coolant (FSV has no soluble poison in its primary coolant of helium) and therefore, is not expected to change at a rate fast enough to justify a comparable surveillance interval. There are, however, several additional questions as to why the requirements are retained in their present form. These questions are listed below.

1) The limiting condition for operation specifies a reactivity change of at least -0.031 delta $k$ but no more than -0.065 delta $k$ due to a core average temperature increase between $22 \hat{\mathrm{v}}^{\circ} \mathrm{F}$ and $1500^{\circ} \mathrm{F}$. This implies that a positive temperature coefficient is permissible at below $220^{\circ} \mathrm{F}$ and above $1500^{\circ}$ F. FSV does not have a specification requiring a minimum reactor coolant loop temperature for criticality. This is reasonable for FSV because there is no way for FSV to heat up the reactor coolant loop sufficiently without expending enormous amounts of power since FSV's primary coolant is helium gas. But since FSV can go critical at low temperatures, and FSV UT/S does not require a negative reactivity temperature coefficient below $220^{\circ} \mathrm{F}$, this implies that FSV can operate at below $220^{\circ} \mathrm{F}$ with a positive temperature coefficient. It is not clear from FSV FSAR Section 14.2 safety analysis, that a reactivity accident at low temperatures (below $220^{\circ} \mathrm{F}$ ) has considered the effects of a positive reactivity temperature coefficient. However, from FSV FSAR Table 3.59, the isothermal and fuel temperature coefficients are shown to be more 
negative at $80^{\circ} \mathrm{F}$ than at $400^{\circ} \mathrm{F}$ or $1520^{\circ} \mathrm{F}$. Therefore, there is reasonable assurance that Fort St. Vrain does not have a positive temperature coefficient at less than $220^{\circ} \mathrm{F}$ core average temperature. The maximum temperature of $1500^{\circ} \mathrm{F}$ is specified because the reactivity temperature coefficient is an integrated coefficient, not a differential coefficient, and thus a temperature range must be specified in order to obtain a meaningful coefficient. This question is RESOLVED.

2) The Old FSV T/S Section 4.1.5 did not specify a maximum negative temperature coefficient for the temperature range of interest. The bases to FSV UT/S explained that the maximum reactivity temperature defect of 0.065 delta $k$ assures that there is sufficient reastivity control to ensure reactor shutdown in the urlikely event that all control rod pairs cannot be inserted and the reserve shutdown system has been actuated. A temperature coefficient greater than 0.065 will make the reserve shutdown system less effective in assuring the reactor remains shutdown when the reactor core cools and thus a limit on the maximum negaiive temperature coefficient for the temperature range of interest is specified. This question is RESOLVED.

3) According to the FSV UT/S Section 3/4.1.5 Bases, the maximum value of the reactivity temperature defect occurs at the beginning of the cycle and slowly decreases through the cycle to a minimum value at the end of the cycle. Since the reactivity temperature coefficient is known to become less regative during the fuel cycle, the reactivity temperature coefficient should be measured at the end of the cycle 'o confirm that it has remained negative throughout the cycle and within the values assumed in the FSV safety analysis, or additional justification should be added to bases explaining why the reactivity temperature coefficient does not need to be measured at the end of the cycle. As ORNL and the NRC staff are pursuing a one-time validation test request at various stages of the fuel cycle with the Licensee for this purpose, this question is RESOLVED.

EVALUATION. With the resolution of all questions, this section is considered CONSISTENT. 


\subsubsection{Reserve Shutdown System-Operating (FSV UT/S Section 3/4.1.6.1)}

DISCUSSION. The requirements of the Reserve Shutdown System under the FSV Operating Modes (Power, Low Power, and Startup) were formerly contained in the Old FSV Sections 4.1.6 (iCO) and 5.1.: (SR).

Amendment 21 to DPR-34 (issued 6/6/79) changed the Bases to Section 5.1.2 to read a minimum $115 \mathrm{psi}$ differential pressure to burst the rupture disc for the reserve shutdown system. This change appear to be a correction of the previous Bases and thus no Safety Evaluation was written.

Amendment 28 to DPR-34 (issued 10/5/82) changed the Bases to Section 4.1.6 by either deleting a portion of the Bases of Section 4.1.6 or moving Section 4.1.7 to next page. In either case no Safety Evaluation was written.

Amendment 33 to DPR-34 (issued 3/8/83) revised Section 5.1 .2 by adding or changing the requirements to operate the ACM (Alternate Cooling Method) quick disconnect valves quarterly, to monitor the $\mathrm{ACM}$ valve actuation gas pressure weekly, to functionally test the low pressure alarm for the reserve shutdown actuating pressure line yearly, to visually examine the pipe sections of this system disassembled and reassembled arter refueling or maintenance, and finally demonstrating at each refueling outage that each subsystem is operable by actuation from the control room. No Safety Evaluation for these items was written.

Section 3/4.1.6.1 of the FSV UT/S is more limiting than the LCO specified by the Old FSV T/S Section 4.1.6. FSV UT/S 3/4.1.6.1 requires all Reserve Shutdown Units (RSUs) to be operable with 1500 psig in the individual He gas bottles and 500 psig in the ACM N $\mathrm{N}_{2}$ bottles which provide a backup means of actuating the RSU hopper pressurization valves. The Old FSV T/S required 6 of 7 RSUs in one hopper subsystem and 29 of 30 RSUs in the other hopper subsystem to be operable, with no minimum gas pressure in the actuation systems specified for system operability. However, the action statement for the Old FSV T/S 4.1.6 is more limiting in that it requires the inoperable RSUs to be made operable within 7 days following a shutdown using the Reserve Shutdown System. FSV UT/S 3/4.1.6.1 action 
statement allows one RSU to be inoperable indefinitely as long as a spare RSU is available, while with two RSUs inoperable, one must be restored to operable status within 24 hours or be in Shutdown within 12 hours after that. Indefinite operation with an inoperable component of a system for which credit is taken in the safety añalysis is unacceptable. The first action statement for FSV UT/S 3/4.1.6.1 should give a definite time for a RSU to be inoperable before restoring it to operable status or the LCO for FSV UT/S 3/4.1.6.1 should written such that 36 out of 37 RSUs must be operable.

FSV UT/S Section 3/4.1.6.1 retains the surveillance requirement for weekly monitoring of the ACM valve actuation gas pressure (to $500 \mathrm{psig}$ ) and quarterly operation of the ACM quick disconnect valves. The functional test of the low pressure alarm for the reserve shutdown actuating pressure line was changed to a Channel Functional Test performed quarterly and a Channel Calibration of the gas pressure instrumentation performed yearly. Visual examination of the pipe sections of the reserve shutdown system disassembled and reassembled after refueling or maintenance and demonstration of system operability after each refueling outage by actuation from the control room has been deleted.

Accurding to FSV FSAR Section 3.8.3.2, Rev. 6, two remotely actuated valves arranged in parallel provide a redundant valve flow path for the helium to enter the hopper in the event of a valve failure. If one valve fails closed, the hopper disc may still be rupiured on opening the other valve. These valves are remote air cylinder operated on-off valves. Each valve is actuated by an electrically power solenoid valve and is operated by instrument air pressure. Air pressure to each. of a pair of helium valves is supplied from a separate and independent instrument air header. The valves have a one second stroke time, fail closed on loss of air or electrical power, and has limit switch to indicate that the valve is fully open. The instrument air pressure is covered by Section $3 / 4.7 .3$ in the FSV UT/S. Presumably, the use of ACM nitrogen $g:$ i allows these valves to operate anc allow helium gas to enter the hopper and rupture the discs even with the loss of electrical power to these solenoid valves. The ACM nitrogen gas could not be used in place of the helium gas to rupture the hopper discs because its pressure is less than the reactor normal operating iressure (700 psi). The hopper rupture discs require 115 psi differential pressure to burst. If it was found necessary to have a surveillance requirement on 
the backup air supply to the solenoid valve controlling the helium supply to the reserve snutdown system, it would seem to be also necessary to have a surveillance requirement on the backup electrical power supplies to the same solenoid valves since boith instrument air supply and electrical power are required in order for the helium supply to burst the rupture discs of the reserve shutdown system. Additional explanation received from the Licensee states that there are two sets of quick disconnect fittings that allow the nitrogen bottles to substitute for the instrument air supply in activating the valves to admit helium to the rupture discs. One set of fittings admits the nitrogen before the solenoid vives. This wuald be used if the instrument air system has failed but electrical power to the solsioid valves was still available. The other set of fittings admits nitrogen directiy to the pneumatic valves that controls the helium flow to the rupture discs. This would overcome the total failure of the normal control systems, i.e. loss of instrument air supply and/or loss of electrical power to the solenoid valves. This is acceptable. however, the set of cuick disconnect fittings before the solenoid valves seem to be irrelevant. This arrangement raises additional questions. Have the nitrogen supply ever been physically connected to the quick connect fittings to assure that the fittings are correct and accessible? Is it necessary to have two sets of fittings if thie set that connects directly to the pneumatic valves will bypass the effects of a sotal loss of normal control systems? Does the procedure which specifies th- connection of the backup nitrogen supply to these fittings identify the different set of fittings? Should a surveillance requirement be added to assure that connection of the backup nitrogen supply to the pneumatic valves to control the helium to the ruptura discs has been practised? Should a surveillance requirement be added to test the eisctrical power to the solenoid valves that control the air supply to the pneumatic valves to assure that the electrical power is operable? Additional explanation is needed in order to answer these questions.

EVALUATION. This section is CONSISTENT. However, additional explanation is needed to answor the questions raised regarding the arrangements of the backup nitrogen supply to the pneumatic valves controlling the helium supply to the rupture discs. 


\subsection{Safe Shutdown Cooling Systems (ESV UT/S Section 3/4.5)}

3.3.1 Helium Circulators-CBCT (Calculated Bulk Core Temperature) Above $\mathbf{7 6 0}$ (FSV UT/S Section 3/4.5.1.1)

DISCUSSION. The requirements on the Helium Circulators with the CBCT (Calculated Bulk Core Temperature) above $760^{\circ} \mathrm{F}$ (Section 3/4.5.1.1 of FSV UT/S) were formerly contained in Old FSV T/S Sections 4.2.1 (LCO), and 5.2.7 (SR).

Amendment 21 to DPR-34 (issued 6/6/79) revised Section 5.2 .7 by requiring an annual functional test by operation on the water turbine (Pelton Wheel) drive using feedwater, condensate, and buosted condensate (supplied to the firewater borster pumps at fire pump discharge pressure). According to the NRC Staff SER supporting thie changes of Amendment 21, this change was made necessary when it was found, while simulating a safe shutdown cooling of the Fort St. Vrain reactor with firewate on $6: 9 / 76$, that the flow through the steam generators and helium circulator speeds did not meet the published FSAR values. In this test, firewater at 125 psig was supplied to the emergency condensate header using the condensate system while the steam generator discharge pressure was being maintained at 75 psig. With these conditions, the flow through the steam generator was about 540 gpm $(270,000 \mathrm{lbms} / \mathrm{hr})$ whereas the FSAR indicated one firewater pump shouiu supply $1400 \mathrm{gpm}$ to the steam generator and drive one helium. circulator to supply about $1.5 \%$ to $2 \%$ helium flow or about $700 \mathrm{rpm}$ for a cold core. Subsequent testing identified and corrected the water flow problem resulting in circulator helium flow consistent with FSAR commitments for shutdown cooling on firewater. However, subsequent reanalysis of the firewater cool down event indicated that temperatures could exceed those predicted in the BSAR for full power operations. It had been established, however, that the systern without the booster pumps was adequate to keep temperatures within FSAR predicted values for operations up to $70 \%$ power. Provision of means for cool down using firewater as a source of feedwater and circulator drive provided a backup means for orderly cool down in the event normally provided sources are lost. Firewater for safe shutdown cooling is routed to the steam generators and helium circulator pelton wheel drives through the emergency condensate or emergency feedwater headers. Two boost pumps increase che firewater pressure differential at the peltinn wheel nozzle to a minimum of 175 
psid, even though operation of only one pump is required. Firewater supply to both pumps is available from two separate headers. The manual supply and routing is from the emergency condensate head and back again through normally open valves. The only action required to obtain the boost pressure is to start either pump once firewater has been admitted to the emergency condensate head. The second source of supply to both pumps is directly tiom the firewater header through two normally closed valves. The discharge from both pumps can also be routed to the emergency feedwater header.

Amendment 33 to DPR-34 (issued 3/8/83) reprinted Section 5.2.7 of the Old FSV T/S under the new page and section numbering system, but did not change any requirements. Therefore, no safety evaluation was performed.

The LCO and Action Statement of FSV UT/S Section 3/4.5.1.1 are consistent with the requirements specified in Old FSV T/S Sections 4.2.1. The Surveillance Requirements of FSV UT/S Section 3/4.5.1.1 are different from the requirements specified in Old FSV T/S Gection 5.2.7. Specifically, the annual test of the safety valves located in the water turbine supply lines, the quarterly functional test of the turbine water removal pumps and turbine water removal tank overflow to the reactor building sump, and the quarterly test and annual calibration of the instrumentation and controls associated with the turbine water removal pumps and the turbine water removal tank overflow to the reactor building sump are missing from FSV UT/S Section 3/4.5.1.1.

The surveillance on the safety valves in the water turbine supply line was removed because these valves are covered by the ASME (American Society of Mechanical Engineers) code and are not in the WSTS. These valves will be retained in the procedures implementing inspection of these valves according to the ASME code. The turbine water removal pumps are tested quarterly under SR 4.5.2.1.a.2 of the FSV UT/S. The instrumentation and controls associated with the turbine water removal pumps and the turbine water removal tank overflow to the reactor building sumn performed only an alarm function and did not initiate any automatic safety action. Therefore, the surveillances on these instrumentation and controls were remov $=\mathrm{d}$ in accordance with the guidelines of the FSV Technical Specification Upgrade Program (TSUP). 
EVALUATION. With the additional information explaining the differences between the Old FSV T/S Surveillance Requirements and the FSV U'T/S Surveillance Requirements, this section is considered CONSISTENT.

\subsection{BCRV and Confinement Systems (FSY UT/S Section 3/4.6)}

\subsubsection{PCRV (Prestressed Concrete Reactor Vessel) Safety Valves (FSV UT/S Section 3/4.6.1.1)}

DISCUSSION. The requirements of the PCRV Safety Valves (Section 3/4.6.1.1 in the FSV UT/S) were formerly contained in Section 4.2.7 (LCO) and 5.2.1 (SR) of the Old FSV T/S.

Amendment 1 to DPR-34 (issued 5/17/74) amended Section 4.2 .7 but did not affect the requirements of Section 3/4.6.1.i of the FSV UT/S.

Ainendment 33 (issued 3/8/83) amended Section $\mathbf{5 . 2 . 1}$ by adding surveillance requirements on the safety valves discharge tank. These surveillance requirements were retained in the FSV UT/S.

The limits specified by FSV UT/S Section 3/4.6.1.1 are supported by FSV FSAR Section 6.8 .

The limits, applicability and action requirements of FSV UT/S 3.6.1.1 were consistent with Old FSV T/S 4.2.7. However, certain differences were noted between rSi UT/S Section 3/4.6.1.1 and old FSV T/S Section 5.2.1:

1) There is a LCO for the irlet block valves to be locked open, but no surveillance requirement for verifying the inlet block valves position. According to the FSV FSAR Section 6.8.2.1, the inlet block valves are locked open and controlled administratively. In addition, there are position indication circuits associated with each block valve. In the Old FSV T/S Section 5.2.1, these position indication circuics associated with the block valves were functionally tested and calibrated when either 
train of the system was tested. This difference is resolved with the addition of a surveiliance requirement to verify the inlet block valve position and for functionally testing and calibrating the position indication circuits associated with block valves to FSV UT/S 3/4.6.1.1.

2) The Bases to FSV UT/S 3/4.6.1.1 states that verification of interspace pressure being less than 5 psig can be made by the absence of alarms or other means. No explanation was offered as to what these other means were or why an absence of alarm was not sufficient to verify that the interspace pressure is less than 5 psig. Further explanation should be added to Bases to FSV UT/S 3/4.6.1.1. Additionally, the Old FSV T/S Section 5.2.1 had a surveillance requirement foi monthly functional testing of the pressure switch and alarm for the interspace pressure and an annual calibration of these same items. As the pressure swith and alarm for the interspace pressure provides only an alarm function and initiates no safety action, it was decided during the development of the UT/S that these circuits would not be included in the Fort St. Vrain UT/S. Therefore, this difference is resolved with the inclusicn of monthly functional testing and an annual calibration of the pressure switch and alarm for interspace pressure in the licensee surveillance procedure that implements the surveillance requirements for this section.

EVALUATION. This section is CONSISTENT except for the surveillance requirements which are DIFFERENT. These differences have been RESOLVED with the inclusions and additions noted.

\subsubsection{Steam Generator/Circulator Penetration Overpressure Protection (FSV UT/S Section 3/4.6.1.2)}

DISCUSSION. The requirements of the steam ge.lerator/circulator penetration overpressure protection is a new section developed to add limiting conditions for operation, made anplicability, action statements and surveillance requirements to the limiting safety system settings for the steam generator penetration interspace pre:ssure rupture discs and safety valves (Section 2.2.1 in the 
FSV UT/S, Section 3.3 in the Old FSV T/S). These limits are re:tined in the FSV UT/S. According to bases to FSV UT/S 3/4.6.1.2 the limit of 5 psig between the rupture disc and the associated safety valve can be verified by the absence of alarms or other means. These other means should be identitied if the absence of alarms is not sufficient to verify this limit. The rupture disc are not of a testable design, therefore, no surveillance requirement can be written to verify the operability of the rupture discs. A surveillance requirement is frovided to visually examine the membrane and knife blade in accordance with the ASME Code test frequency and test requirements

\section{EVALUATION. This section is CONSISTENT.}

\subsubsection{Interspace Minimum Pressurization (FSV UT/S Section 3/4.6.1.3)}

DISCUSSION. The requirements of the Interspace Minisum Pressurization (Section 3/4.6.1.3 of the FSV UT/S) were formerly contained in Section 4.2.7 (LCO) and Section 5.2.15 (SR) of the Old FSV T/S.

Amendment 1 to DPR-34 (issued 5/17/74) amended some requirements to Section 4.2 .7 but did not affect the requirements of Section $3 / 4.6 .1 .3$ of the FSV UT/S.

Amendment 24 (issued 11/9/81) allowed interspace helium leakage from the steam generator interspace to the cold reheat steam system and granted temporary relief to operate steam generator module B-2-3 interspace at below prima:y coolant pressure but above cold reheat steam pressure. The NRC Staff SER to Amendment 24 evaluated the proposed changes and found them acceptable.

Ainendment 26 (issued 3/18/82) made more changes to allow interspace helium leakage from the steam generator interspace to the cold reheat steam system. The NRC Staff SER to Amendment 26 provided additional discussion of the interspace helium leakage from the steam generato: interspace to the cold reheat steam system and the possible radiological gaseous releases that could result. Amendment 33 (issued 3/8/83) amended the surveillance requirements for interspace helium leakage. No NRC Staff SER was provided for interspace heliur. leakage presumably because it was incorporated in previous communications. 
The limits specified by FSV UT/S Section 3/4.6.1.3 are consistent with the lirnits specified by the Old FSV Section 4.2.7. In addition to interspace pressure limits, there is also a limit on interspace helium mass leakage from the steam generator interspace to the cold reheat steam system (FSV UT/S Section 3/4.6.1.5). The following differences were noted between the two specifications:

1) The time period allowed for corrective action before requiring reactor shutdown by Section 4.2.7 of the Old FSV T,S was 12 hours. The time period allowed for corrective action before requiring reactor shutdown by Section 3/4.6.1.3 of the FSV UT/S is 24 hours. The time period allowed for reactor shutdown by Section 4.2 .7 of the Old FSV T/S was not stated. The time period allowed for SHUTDOWN by Section 3/4.6.1.3 of the FSV UT/S is 24 hours. Failure to meet the LCO requirements of FSV UT/S 3/4.6.1.3 could mean the leakage of contaminated primary coolant (Helium) from the PCRV. The increase of 12 hours for corrective action before requiring FSV to go to the SHUTDOWN mode is based on the consistency with the overall approach of allowing orderly shutdowns. The radiological hazard from this change is expected to be minimal. In addition, the radiological effluent section which is not part of the FSV T/S Upgrade Program and therefore, has not been changed, still requires immediate shutdown if the Maximum Permissible Concentrations (MPCs) for gaseous radiological effluent are exceeded. Since ar immediate shutdown is required by the FSV Radiological Effluent T/S (Section 8.1.1) if the gaseous radiological effluent MPCs are exceeded, this question is now considered RESOLVED.

2) Surveillance interval on PCRV interspace pressure is now 24 hours. The previous surveillance requiremen: (Old FSV T/S Section 5.2.15) was a monthly functional testing of the instrumentation which monitored the pressure differential between the purified helium supply header to the PCRV penetration interspaces and the primary coolant system and annual calibration of these same item. As the instrumentation that monitors the pressure differential between the purified helium supply header to the PCRV penetration interspaces and the primary coolant 
system performs only an alarm function for the reactor cyerators and does not initiate any automatic safety action, the monthly functional testing and annual calibration of this instrumentation has been deleted in accordance with the guidelines developed for the FSV T/S Upgrade Program. This question is now considered RESOLVED.

EVALUATION. With the additional explanation for the questions raised, this section is now considered CONSISTENT.

\subsubsection{Reactor Plant Cooling Water/PCRV Liner Cooling System-Operating (FSV UT/S Section 3/4.6.2.1)}

DISCUSSION. The requirements on the Reactor Plant Cooling Water/PCRV Liner Cooling System-Operating (Section 3/4.6.2.1 of the FSV UT/S) were formerly contained in Sections 4.2.13 and 4.2.14 (LCO) and Sections 5.4.5 and 5.4.11 (SR) of the Old FSV $\mathrm{T} / \mathrm{S}$.

Amendment 1 to DPR-34 (issued 5/17/74) added Section 4.2.13 to the FSV Old $T / S$ which was inadvertently ornitted from the initial printing. No safety evaluation was necessary.

Amendment 51 to DPR-34 (issued 4/22/87) extended the annual calibration of the flow scanner instruments and alarms and the six subheader flowmeters to the next scheduled plant shutdown if they were not calibrated during the previous year. The SER accompanying Amendment 51 stated that this extes:sion was acceptable up to a surveillance internal not to exceed 18 months since the potential for additional plant transients is reduced and since the WSTS, in general, specifies surveillance intervals not to exceed 18 months when utilizing intervals of shutdown or refueling.

The Limiting Condition for Operation on the Reactor Plant Cooling Water/PCRV Liner Cooling System in FSV UT/S 3/4.6.2.1 are essentially the same as the requirements in the Old FSV T/S 4.2.13 and 4.2.14. The Action Statements of the Old FSV T/S 4.2.13 and 4.2.14 have been retained and more Action Statements added to provide additional guidance when less than the required number of PCRV 
Liner Cooling System tubes are operating or when the Liner Cooling System tube temperature rise is greater than the acceptance criteria of SR. 4.6.2.1.b. The intervals in the Action Statements of FSV UT/S 3/4.6.2.1 are consistent with the intervals given in Old FSV T/S 4.2.13 and 4.2.14. The Surveillanc: Requirements in FSV UT/S 3/4.6.2.1 refer to the actua: minimum flow required in order for the PCRV Liner Cooling System to perform its intended function and the actual tempe:ature limits rather than the flo scanner cir suits and temperature indicting circuits as specified by the Old FSV T/S 5.4.5. Surveying the flow and temperature limits rather than the flow and temperature alarm circuits is an acceptable alternative to the testing and calibrating of these alarm circuits as it directly refers to the Limiting Conditions for Operations. Also, the testing and calibrating of the alarm circuits should be covered by the surveillance procedures. Finally, surveying the temperature limits rather than the alarm circuits is consistent with the general upgrade philosophy of deleting those surveillance requirements on instrumentation circuits that perform only alarm function and no automatic actuation of safety-related systems.

EVALUATION. This section is CONSISTENT.

3.4.5 Reactor Plant Cooling Water/PCRV Liner Cooling System Temperatures (FSV UT/S Section 3/4.6.3)

DISCUSSION. The requirements on the Reactor Plant Cooling Water/PCRV Liner Cooling System Temperatures (Section $3 / 4.0 .3$ of the FSV UT/S) were formerly contained in Section 4.2.15 (LCO) and Section 5.4.4 and 5.4.5 of the Old FSV T/S.

The Limiting Condition for Operation on the Reactor Plant Cooling Water/PCRV Liner Cooling System Temperatures in FSV UT/S 3/4.6.3 are the same as the requirements in the Old FSV T/S 4.2.15. The surveillance requirements on the Reactor Plant Cooling Water/PCRV Liner Cooling System Temperatures in FSV UT/S 3/4.6.3 are not the same the in Section 5.4.4 of the Old FSV T/S. The new surveillance requirements refer to the actual ternperature limits rather than the testing and calibrating the temperature alarm circuits. Additionally, the surveillar.ce intervals have been decreased to 24 hours instead of monthly testing and annual 
calibration as in the Old FSV T/S. Surveying the temperature limits rather than the temperature alarm circiits is an acceptable alternative to the testing and calibrating of these alarm circuits as it directly refers to the Limiting Conditions for Operations. Also, the testing and calibrating of the alarm circuits should be covered by the surveillance procedures. Finally, surveying the temperature limits ratier than the alarm circuits is consistent with the general upgrade philosophy of deleting those surveillance requirements on instrumentation circuits that perform only alarm function and no automatic actuation of safety-related systems.

EVALUATION. This section is CONSISTENT except for the surveillance requirements, which are considered CONSERVATIVE and therefore acceptable.

\subsection{Auxiliary Electric Power Systems (FSV UT/S Section 3/4.8)}

\subsubsection{AC Power Sources-Operating (FSV UTiS Section 3/4.8.1.1)}

DISCUSSION. The requirements on the AC Power Sources under the FSV Operating Modes (Power, Low Power, and Startup) were formerly contained in Old FSV T/S Sections 4.6.1 (LCO) and 5.6.1 (SR). AC Power Sources covered by FSV UT/S Section 3/4.8.1.1 include the Unit Auxiliary Transformer (UAT), the Main Power Transformer (MPT), the Reserve Auxiliary Transformer (RAT) and the Standby Diesel Generators (SDGs).

Amendment 22 to DPR-34 (issued 8/19/80) changed the amount of diesel fuel in each diesel generator set day tank to 325 gallons. Originally, the limit was set at 500 gallons. The day tank level control system does not start to refill the tanks until the level reaches 350 gallons. Each day tank is of $500 \mathrm{gal}$. capacity and when the diesel generator is operating, the tank level decreases below the 500 gal. mark without being refilled. If the operation of the diesel generator is stopped when the: day tank level is between 500 and 350 gallons, the fuel oil pump is not started automatically and the day tank level will remain below the 500 gal. limit, thereby requiring manual topping off. The NRC staff safety evaluation of this change accepted the 325 gal. supply of fuel oil in each day tank as sufficient to bring en.-igency electric supplies on line at load without interruption owing to iradequate fuel supply prior to transfer of fuel from the main storage tank. 
Amendment 25 to DPR-34 (issued 3/2/82) specified the period of time and conditions under which the Unit Auxiliary Transformer (UAT) can be removed from service with the reactor at power. The previous FSV T/S did not specify the time frame or conditions for the removal of the UAT from service. The addition to the FSV T/S of a 24 hour time period when the UAT may be inoperable (taken out of service), as well as the requirement that for inoperability, both station diesel generator sets must be started immediately before taking the UAT out of service, their controls subsequently placed in the automatic mode, and all three 480 volt AC essential buses operable was judged by the NRC Staff in their safety evaluation of this change to be consistent with the former requirements on the Reserve Auxiliary Transformer (RAT). The specification of the conditions under which the UAT may be removed from serviced provided an alternate source of power to equipment necessary for the safe shutdown of the plant.

Amendment 34 to DPR-34 (issued $3 / 21 / 83$ ) revised the FSV T/S to allow continued operation of the FSV station for 10 days while repairs were being completed to the Unit Auxiliary Transformer. This was a temporary change requested by the Licensee on March 9, 1983 following a failure of the UAT on the morning of March 9, 1983 with repairs to the UAT taking about the 10 days. The previous allowed outage time for the UAT was 24 hours. Included in the request was a commitment by the Licensee to verify the operability of each Station Diesel Generator at least once every 24 hours, to ensure continued operability of all three 480 volt $A C$ essential buses and to limit reactor power to less than $30 \%$ thermal power. Based on the Licensee's commitment for increased surveillances on the Station Diesel Generators and reduced reactor power, plus the fact that there were six sources of power available to the Reserve Auxiliary Transformer (RAT) (which serves as the normal source of facility electrical power during periods of plant shutdown and startup) and plus the fact that the Alternate Cooling Method (ACM) Diesel Generator was also available to provide another independent source of power for emergency electrical loads, the NRC Staff accepted the request for this temporary change.

Amendment 54 to DPR-34 (issued 5/20/87) modified the surveillance requirements for the Standby Diesel Generators semiannual tests and the tests 
performed during the refueling outages. According to the NRC Staff Safety Evaluation, during power operation of the plant, starting an Emergency (Standby) Diesel Generator (EDG) automatically on a simulated loss of offsite power does not induce any transient or perturbation in the Class $1 \mathrm{E}$ electric distribution system at FSV. However, the verification of the operability of the load sequencer causes separation of emergency buses from the offsite power source, load shed, and restarting of the loads on the onsite EDG power source. This may induce severe disturbance in the Class $1 \mathrm{E}$ electric distribution system, affecting normally operating equipment, and may cause the unit to trip. The Licensee believed that deliberately induced upsets should be minimized during plant operation. Additionally, minimizing plant trip and restart enhances overall plant reliability and decreases challenges to the safety systems. To avoid this potential risk, the licensee proposed to remove verification of load sequencer operability from the semi-annual test schedule to once per refueling cycle, not to exceed 18 months. The licensee's proposal also included conducting a once per refueling cycle test in lieu of the scheduled semi-annual test. The NRC staff found it acceptable on the basis that the semi-annual test on the EDGs demonstrated the operability of the EDGs and its automatic controls, which is included in the once per refueling cycle test.

By removing the load sequencer operability test from six months to once per operating cycle, the EDG's full load test will also be once per refueling cycle. This is less conservative because the semi-annual test will no longer verify the capacity and capability of the EDGs for the full load operation. 20 CFR Appendix A GDC 18 requires periodic iesting of the operability of a protective system as a whole and, under conditions as close to design as practical. In response to the NRC staff's concerns, the licerisee stated that the EDGs were loaded to at least $1200 \mathrm{~kW}$ for a period of 2 hours in the weekly test. Old FSV T/S 5.6.1.a required that the EDGs to be loaded to at least $50 \%$ of their rated full load capacity $(1210 \mathrm{~kW})$ in the weekly test. The licensee's written procedure loaded $1200 \mathrm{~kW}$ on each EDG in the weekly test. Additionally, the licensee submitted a draft revision of the FS' T/S which followed the standard T/S format and included full load testing of the EDGs during plant operation. Until the revised FSV T/S were approved, the NRC staff accepted the licensee's surveillance procedure for load testing of the EDGS on a weekly basis with the understanding that the resident inspector's would verify of the licensee's EDG weekly test procedure during the interim period. 
The proposed change also included increasing the minimum allowable interval between the semi-annual test schedule from four months to six months. The maximum allowable interval hetween the semi-annual test remained eight months. The maximum combined time interval for three consecutive tests was changed to not exceed 20 months. This was more conservative the previous allowance of maximum of 24 months as combined time interval for three consecutive semi-annual tests on the EDGs. The NRC staff found that change to be conservative and, therefore, acceptable.

The LCOS of FSV UT/S Section 3/4.8.1.1 are consistent with the requirements specified in Old FSV T/S Section 4.6. However, there were several LCOs present in Old FSV T/S Section 4.6 which were not present in the FSV UT/S Electrical Section. These LCOs are the requirement on the PPS battery charger/inverter and the instrument iiverters operability, and the requirement on at least one Boiler Fuel Oil Pump operable between the auxiliary boiler fuel supply and the diesel fuel oil day tanks. The LCO requirement on the PPS battery charger/inverter and the instrument inverters may be included with FSV UT/S Section 3/4.8.3 Onsite Power Distribution and their perceived exclusion may be due to the use of different nomenclature for the same system. This should be clarified in firther discussion with the NRC Staff. The requirement on the Boiler Fuel Oil Pump operability is not a requirement which should be retained in the FSV UT/S because this component is not part of a system for which credit is taken in the safety analysis, it is not a safety grade system, nor is it even a support system to a safety system. However, further discussion should be added at least to the Technical Evaluation Report on the deletion of this requirement on the Boiler Fuel Oil Pump operability and the reasons for its deletion.

The requirements of the Action Statements of FSV UT/S Section 3/4.8.1.1 contained essentially the same requirements of the Action Statements of the Old FSV T/S Section 4.6 with additional Action Statements added to FSV UT/S 3/4.8.1.1 to provide additional guidance when more than one component specified by LCO 3.8.1.1 are inoperable. 
The Surveillance Requirements of FSV UT/S Section 3/4.8.1.1 has added weekly and once per refueling cycle requirements on the off site sources of $A C$ electric power which were previously lacking from the Old FSV T/S Section 4.6. Additional detailed Surveillance Requirements have been added on the demonstration of the operability of the diesel generators which are consistent with the standard surveillance practices being used at plants recently licensed for operation.

EVALUATION. This section is CONSISTENT.

\subsubsection{AC Power Sources-Shutdown (FSV UT/S Section 3/4.8.1.2)}

DISCUSSION. The requirements on the AC Power Sources under the FSV Shutdown Operating Mode were formerly contained in Old FSV T/S Sections 4.6.1 (LCO) and 5.6.1 (SR). AC Powe: Sources covere' by FSV UT/S Section 3/4.8.1.2 include the Unit Auxiliary Transformer (UAT), the Main Power Transformer (MPT), the Reserve Auxiliary Transformer (RAT) and the Standby Diesel Generators (SDGs).

Amendment 22 to DPR-34 (issued 8/19/80) changed the amount of diesel fuel in each diesel generator set day tank to 325 gallons. As for AC Power Sources under FSV Operating Modes, the NRC Staff Safety Evaluation of this change found it to be acceptable.

Amendment 25 to DPR-34 (issued 3/2/82) specified the period of time and conditions under which the Unit Auxiliary Transformer can be removed from service with the reactor at power. As for AC Power Sources under FSV Operating Modes, the NRC Staff Safety Evaluation of this change found it to be acceptable.

Amendment 34 to DPR-34 (issued 3/21/83) revised the FSV T/S to allow continued operation of the FSV station for 10 days while repairs were being completed to the Unit Auxiliary Transformer. This was a temporary change requested by the Licensee on March 9, 1983 following a failure of the UAT on the morning of March 9, 1983 with repairs to the UAT taking about the 10 days. The previous allowed outage time for the UAT was 24 hours. As for AC Power Sources 
under FSV Operating Modes, the NRC Staff Safety Evaluation of this temporary change found : to be acceptable.

Amendment 54 to DPR-34 (issued 5/20/87) modified the surveillance requirements for the Standby Diesel Generators semiannual tests and the test performed during the refueling outages. As for AC Power Sources under FSV Operating Modes, the NRC Staff Safety Evaluation of this change found it to be acceptable.

\section{EVALUATION. This section is CONSISTENT.}

\subsubsection{ACM Diesel Generator (FSV UT/S Section 3/4.8.4)}

DISCUSSION. The requirements of the ACM Diesel Generator (Section 3/4.8.4 in the FSV UT/S) were formerly contained in Section 4.2.17 (LCO) and 5.2.20 and 5.2.21 (SR) of the Old FSV T/S.

Amendment 18 to DPR-34 (issued 10/28/77) added the original LCO requirements on the ACM Diesel Generator to the Fort St. Vrain Facility Operating License. The original requirement was for operability of the IACM Diesel Generator with at least 850 gallons of fuel in storage to provide for at least 24 hours of operation at full load. The LACM Diesel Generator was required to be checked weekly and tested monthly for two hours at half load. In addition, the valves and electrical switches that must be manually positioned to implement the LACM must be tested twice annually at an interval between tests of 4 to 8 months. According to the Safety Evaluation Report accompanying Amendment 18, this was considered an Interim Alternate Cooling Method (IACM) to provide electrical power for decay heat removal if a disabling fire or electrical fault were to make the dedicated (standby) diesel generators unavailable and the reactor operated at less than $70 \%$ power. The IACM Diesel Generator was a trailer mo'unted $600 \mathrm{~kW}, 480 \mathrm{~V}$ diesel generator that provided an alternate source of AC electrical power, independent of normal offsite and onsite emergency power sources. The IACM Diesel Generator provided power for plant lighting, stack monitoring, operation of pumps and valves which must be utilized in depressurizing the reactor, operation of a plant einaust fan, and operation of a pump to supply makeup from a water storage basin, as necessary, to 
the cooling tower basin. The emergency lightning and stack monitor were the only loads automatically transferred to IACM power when the diesel generator is started. All other loads were transferred mianually. The time necessary to place the IACM in full service was judged to be about two to four hours.

Amendment 22 to DPR-34 (issued 8/19/80) changed LCO 4.2.17 and SR 5.2.20 to cover the ACM Diesel Generator and to allow Fort St. Vrain operation beyond $70 \%$ power. The fuel storage operability requirement was changed to at least 10,000 gallons of fuel total in storage and added operability requirements on the fuel oil transfer purip from the fuel oil storage tanks to the diesel fuel oil day tank and on the associated switchgear and motor control center. The requirement on 10,000 gallons of fuel total was based on 108 hours ( 4.5 days) operation at full load ( $900 \mathrm{~kW}$ ). An action statement was also added which allowed 7 consecutive days or a total of 21 days in a three month period for the ACM diesel generator to be inoperable for performance of maintenance while the reactor was at powtr. A surveillance requirement was changed to monthly testing at $100 \%$ power.

Amendment 51 to DPR-34 (issued 4/22/87) retitled surveillance requirement 5.2.21 from "Handvalve and Transfer Switch Surveillance" to "ACM Transfer Switches, Valves, and Instrument Surveillance" and maintained the operability check of this equipment at the original surveillance interval (4 to 8 months) but changed the full functional test to e performed at the refueling intervals not to exceed 18 months. This was accepted by the NRC staff in the accompanying SER to Amendment 51 .

Fort St. Vrain Updated FSAR Rev. 6 Section 8.2.8 statt.s that the ACM Diesel Generator is a non-class $1 \mathrm{E}, 4.16 \mathrm{kVAC}, 60 \mathrm{~Hz}$ diesel generator rated at $2500 \mathrm{~kW}$ continuous duty. The only load automatically transferred to the $A C M$ with the failure of normal power is plant lighting, all other loads being manually transferred.

The requirements on the ACM Diesel Generator in FSV UT/S 3/4.8.4 are generally the same as the requirements in the Old FSV T/S Sections 4.2 .17 (LCO) and 5.2.20 and 5.2.21 (SRs) as amended by Amendments 22 and 51 with the addition of the I r,de applicability requirement, an additional action statement (Action b) whici gives guidance on what should be done if the fuel oil samples taken per 
Surveillance Requirement 4.8.4. are unacceptable, and additional surveillance requirements on the $A C M$ Diesel Generator. The additional surveillance requirtments on the ACM Diesel Generator are consistent with the surveillance requirements on the Standby Diesel Generators (FSV UT/S 3/4.8.1.1) and are, in general, consistent with the Westinghouse STS surveillance requirements on emergency diesel generators. However, one difference is noted between the FSV UT/S 3/4.8.4 and the FSV Old T/S 5.2.21. This difference is the lack of a surveillance requirement on the full functional tests on the hand valves which must be used during the transfer from normal cooling to ACM operation. As noted by Amendment 51, the NRC staff agreed to a full functional test of the hand valves and electrical switches to be performed at the refueling interval, not to exceed 18 months. The full functional test of the electrical switches have been retained in the FSV UT/S at the 18 month surveillance test (SR 4.8.4.d). No explanation could found in the Bases to FSV UT/S 3/4.8.4 or in the TER prepared by INEL [Ref. 4] as to why a full functional test of the hand valves was not retained in the FSV UT/S. The furl functional testing of the hand valves may be covered in the appropriate FSV UT/S sections on the applicable piping systems or by the Inservice Inspection and Testing Program. If this is the case, this should be explained in the Bases to FSV $\mathrm{UT} / \mathrm{S} 3 / 4.8 .4$. If this is not the case, a surveillance requirement should be added to FSV UT/S 4.8.4 on the full functional testing of the hand valves used during the transfer from normal cooling to ACM operation at the refueling interval, not to exceed 18 months.

EVALUATION. This section is CONSISTENT except for the lack of surveillance requirement on the full functional testing of the hand valves used to implement ACM operation. With the addition of more explanation to the Bases to FSV UT/S 3/4.8.4 regarding the full functional testing of the hand valves being covered by the Inservice Inspection and Testing Program, this difference is considered resolved.

\subsection{SUMMARY AND CONCLUSION}

Based on the technical audit of the FSV UT/S for consistency and safety conservatism with respect to the FSV Updated FSAR, the FSV SER, the FSV Facility 
Operating License DPR-34, and amendments 1 to 60 to DPR-34, and Appendix A to DPR-34, LLNL judges all audited sections to be either CONSISTENT or CONSERVATIVE. All noted DIFFERENCES have been resolved with the changes or discussions given in the evaluation portion of each audit section.

\subsection{REFERENCES}

[1] Technical Evaluation Report for Review of Fort St. Vrain Technical Specification Upgrade Program, D.L. Moses, Oak Ridge National Laboratory, Oak Ridge, TN. July 1988.

[2] Technical Evaluation Report, the Acceptability of Fort St. Vrain Upgraded Technical Specifications for Structures, Systems, and Components with Safety-Related and Importaní-to-Safety Cooling Functions, D.L. Moses, Oak Ridge National Laboratory, Oak Ridge, TN. July 1988.

[3] EGG-NTA-7795 Technical Evaluation Report for Review of Fort St. Vrain Technical Specification Upiade Program. J.C. Stackew, Idaho National Engineering Laboratory, EG\&G Idaho, Inc., Idaho Falls, ID. July 1988.

[4] EGG-NTA-7890 Technical Evaluation Report for Review of Fort St. Vrain Upgraded Technical Specifications: Section 3/4.8 - Auxiliary blectric Power Systems, Alan C. Udy, Idaho National Engineering Laboratory, EG\&G Idaho, Inc., Idaho Falls, ID. July 1988.

[5] Fort St. Vrain Updated Final Safety Analysis Report (FSAR), Revision 6. (No date available).

[6] Safety Evaluation by the Division of Reactor Licensing, U.S. Atomic Energy Commission in the Matter of Public Service of Colorado Fort St. Vrain Nuclear Generating Station, Docket No. 50-267, Facility Operating License No. DPR-34. January 20, 1972. 
77 Public Service Company of Colorado Fort St. Vrain Nuclear Generating Station, Docket No. 50-267, Facility Operating License No. DPR-34. December 21, 1973. 


\section{APPENDIX A.1}

Appendix A to Facility Operating License DPR-34 (Old Fort St. Vrain Technical Specifications) Table of Contents, As Amended to Amen lment $60(6 / 20 / 88)$ with Cross-Reference to Upgrar' ed Fort St. Vrain Technical Specification Sections.

\section{Table of Contents}

I Introduction

2 Definitions (new 1.0)

3 Safety Limits and Limiting Safety System Settings

3.1 Reactor Core Safety Limit (new 2.1.1, 3/4.2.6)

3.2 Reactor Vessel Pressure Safety Limit (new 2.1.2)

3.3 Limiting Safety System Settings (new 2.2)

4 Limiting Conditions for Operation (new 3/4.0)

4.1 Reactor Core Reactivity Control

4.1.1 Core Irradiation (new 3/4.2.1)

4.1.2 Operable Control Rods (new 3/4.1.1, 3/4.1.3)

4.1.3 Rod Sequence (new 3/4.1.4.1, 3/4.1.4.2)

4.1.4 Partially Inserted Rods (new 3/4.1.4.1, 3/4.1.4.2)

4.1.5 Reactivity Change with Temperature (new 3/4.1.5)

4.1.6 Reserve Shutdown System (new 3/4.1.6)

4.1.7 Core Inlet Orifice Valves (new 3/4.2.2, 3/4.2.3)

4.1.8 Reactivity Status (new 3/4.1.7)

4.1.9 Core Region Temperaiure Rise (new 3/4.2.4)

4.2 Primary Coolant System

4.2.1 Number of Operable Circulators (new 3/4.5.1)

4.2.2 Operable Circulator (new 3/4.5.1)

4.2.3 Turbine Water Removal Pump

4.2.4 Service Water Pumps (new 3/4.7.4.1, 3/4.7.4.2)

¡.2.5 Circulating Water Makeup System

4.2.6 Fire Water System/Fire Suppression Water System (new 3/4.5.5)

4.2.7 PCRV Pressurization (new 3/4.6.1.1, 3/4.6.1.3) 
Primary Coolant Activity (new 3/4.4.2) PCRV Closure Leakage (new 3/4.6.1.4)

Loop Impurity Levels, High Temperatures (new 3/4.4.3)

Loop Impurity Levels, Low Temperatures (new 3/4.4.4)

Liquid Nitrogen Storage

PCRV Liner Cooling System (new 3/4.6.2)

PCRV Liner Cooling Tubes (new 3/4.6.2)

PCRV Cooling Water System Temperatures (new 3/4.6.3)

DELETED-Amendment 21 (6/6/79), Added Amendment 14 (6/18/76)

(Diesel-Driven Pumps IACM)

Diesel-Driven Generator for ACM-Added Amendment 18 (10/28/77 (new 3/4.8.4)

Primary Coolant Depressurization-Added Amendment 18 (10/28/77) (new 3/4.7.5)

Firewater Booster Pumps-Added Amendment 21 (6/6/79) (new 3/4.5.1)

\section{Secondary Reactor Coolant System}

Steam Generators (new 3/4.5.3)

Boiler Feed Pumps (new 3/4.7.1.1)

Steam/Water Dump Tank Inventory (new 3/4.7.1.2)

Emergency Condensate and Emergency

Feedwater Headers (new 3/4.j.4)

Storage Ponds

Instrument Air System (new 3/4.7.3)

Hydraulic Power System (new 3/4.7.2)

Secondary Coolant Activity (new 3/4.7.1.4)

DELETED-Amendment 21 (6/6/79) (High Pressure Helium Supply System)

Shock Suppressors (Snubbers) (new 3/4.7.7)

Instrumentation and Control Systems

Plant Protective System Instrumentation (new 3/4.3.1)

Control Room Temperature (new 3/4.3.3)

Area Radiation Monitors (new 3/4.3.2.2)

Seismic Instrumentation (new 3/4.3.2.3)

Analytical System Primary Coolant Moisture Instrumentation (new 3/4.3.2.1) 
4.4.6 Room Temperature, 480 Volt Switchgear-A.dded Amendment 18 $(10 / 28 / 77)$

4.5 Confinement System

4.5.1 Reactor Building (new 3/4.6.5.1, 3/4.6.5.2, 3/4.5.5.3)

4.5.2 Reactor Vessel Internal Maintenance

4.6 Auxiliary Electric Power System

4.6.1 Auxiliary Electric System (new 3/4.8.1.1, 3/4.8.1.2)

4.7 Fuel Handling and Storage Systems

4.7.1 Fuel Handling in the Reactor (new 3/4.9.1)

4.7.2 Fuel Handling Machine (new 3/4.9.3)

4.7.3 Fuel Storage Facility (new 3/4.9.4)

4.7.4 Spent Fuel Shipping Container (new 3/4.9.5)

4.8 Radioactive Efflueni Disposal System (Superseded by

Section 8.0-Amendment 37 (11/23/83))

4.9 Fuel Loading and Initial Rise to Power

4.9 .1

4.9 .2

4.9 .3

Fuel Loading and Initial Rise to Power

Plant Protection System Dew Point Moisture Monitor Tests During Phase 2

Xenon Stability Testing-Added Amendment $49(12 / 15 / 86)$ (new 3/4.10.1)

4.10 Fire Suppression Systems

4.10.1 Room Isolation Dampers, Three Room Control Compicin-Added Amendment 18 (10/28/77)

4.10.2 Halon Fire Suppression Systems, Three Room Control Complex Added Amendment 18 (10/28/77) (new 3/4.7.6.3)

4.10.3 Smoke Detectors and Alarms for Three Room Control Complex and Congested Cable Areas-Added Amendment 18 (10/28/77) (new 3/4.3.2.8)

4.10.4 Fire Barrier Penetration Seals-Ad̉Jed Amendment $18(10 / 28 / 77)$ (new 3/4.7.7)

4.10.5 Fixed Water Spray Systems-Added Amendment $21(6 / 6 / 79)$ (new 3/4.7.6.1)

4.10.6 Carbon Dioxide Fire Suppression Syste.as, Emergency Diesel Generator Rooms-Added Amendment 22 (8/19/80) (new 3/4.7.6.2)

4.10.7 Fire Hose Stations-Added Amendment 22 (8/19/80) (new 3/4.7.6.4) 

$(8 / 19 / 80)$ (new 3/4.7.6.5)

5 Surveillance Requirements (new 3/4.0)

5.1 Reactor Core and Reactivity Control

Reserve Shutdown System (new 3/4.1.6)

Temperature Coefficient (new 3/4.1.5)

5.1 .4

Reactivity Status (new 3/4.1.7)

5.1 .5

Withdrawn Rod Reactivity (new 3/4.1.4.1, 3/4.1.4.2)

5.1 .6

Core Safety Limit

5.1 .7

Region Peaking Factor-Added Amendment 28 (10/5/82) (new 3/4.2.2, 3/4.2.3)

5.1.8 (?) Core Irradiation (new 3/4.2.1)

$5.1 .9(?)$

Core Region Temperature Rise (new 3/4.2.4)

5.1 .8

5.2 Minimum Helium Flow/Maximum Core Region Temperature Rise Added Amendment 57 (11/23/87)

Primary Coolant System

PCRV and PCRV Penetration Overpressure Protection (new 3/4.6.i.1)

Tendon Corrosion and Anchor Assemblies (new 3/4.6.4)

5.2 .4

Tendon Load Cell (new 3/4.6.4)

PCRV Concrete Structure (new 3/4.G.4)

Liner Specimen (new 3/4.6.4)

Plateout Probe

Water Turbine Drive (new 3/4.5.1, 3/4.5.3, 3/4.5.4, 3/4.7.1.1)

Bearing Water Makeup Pump (new 3/4.5.1)

5.2 .10

5.2 .11

Helium Circulator Bearing Water Accumulators (new 3/4.5 1)

5.2 .12

Fire Water System/Fire Suppression Water System (new 3/4.5.5)

5.2 .13

Primary Reactor Coolant Radioactivity (new 3/4.4.2)

5.2 .14

Primary Reactor Coolant Chemical (new 3/4.4.3, 3/4.4.4)

5.2 .15

PCRV Concrete Helium Permeability

PCRV Liner Corrosion

5.2 .16

PCRV Penetration Interspace Pressure (new 3/4.6.1.3)

5.2 .17

PCRV Closure Leakage (new 3/4.6.1.4)

DELETED-Amendment 33 (3/8/83), Added Amendment $12(4 / 26 / 76)$

(Helium Circulator Pelton. Wheels) 
5.2.18

5.2.19

5.2 .20

5.2.21

5.2 .22

5.2 .23

5.2.24

5.2.25

5.2.26

5.2.27

5.2 .28

5.3

5.3.1

5.3.2

5.3.3

5.3.4

5.3 .5

5.3.6

5.3.7

5.3.8

5.3 .9

5.3.10

5.3.11

5.3.12

5.4

5.4.1

5.4.2

5.4.3

5.4 .4

Helium Circulators-Added Amendment 12 (4/26/76)

DELETED-Amendment 21 (6/6/79), Added Amendment 14 (6/18/76) (IACM Diesel-Driven Pumns)

ACM Diesel Driven Generator-Added Amendment 18 (10/28/77)

(new 3/4.8.4)

Hand Valve and Transfer Switch-Added Amendment 18 (10/28/77)

PGX Graphite-Added Amendment 20 (4/20/79) (new 3/4.4.3)

Firewater Booster Pump-Added Amendment $21(6 / . / 79)$ (new 3/4.5.1)

Reactor Auxiliary Cooling Trater Systems-Name change Amendment 33 (3/8/83), (Circulating Water Makeup System)-Added Amendment 22 (8/19/80)

Core Support Block-Added Amendment 33 (3/8/83) (new 3/4.4.3)

Region Constraint Devices-Added Amendment 33 (3/8/83) (new 3/4.2.5)

Helium Shutoff Valves-Added Amendment 33 (3/8/83) (new 3/4.2.5)

PCRV Penetrations and Closures-Added Amendment 33 (3/8/83) Secondary Coolant System

Steam/Water Dump System (new 3/4.5.3, 3/4.5.4, 3/4.7.1.2)

Mair. and Hot Reheat Steam Stop Check Valves

Bypass and Pressure Relief Valves (new 3/4.7.1.3)

Safe Shutdown Cooling Valves

Hydraulic Power System (new 3/4.7.2)

Instrument Air System (new 3/4.7.3)

Secondary Coolant Activity (new 3/4.7.1.4)

Shock Suppressors (Snubbers) (new 3/4.7.7)

Safety Valves (new 3/4.7.1.5, 3/4.7.1.6

Secondary Coolant System Instrumentation (new 3/4.5.3)

Steam Generator Bimetallic Welds (new 3/4.5.3)

Steam Generator Tube Leaks (new 3/4.5.3)

Instrumentation and Control Systems

Reactor Protective System and Other Cirtical Instrumentation and Control Checks, Calibrations and Tests (new 3/4.3.1)

Control Room Smoke Detector (new 3/4.3.2.8)

Core Region Outlet Temperature Instrumentation

PCRV Coolin ${ }_{\mathfrak{\xi}}$ Water System Temperature Scanner (new 3/4.6.2) 
PCRV Cooling Water System Flow Scanner (new 3/4.6.3)

Core Delta P Indicator

Control Room Temperature (new 3/4.3.3)

5.4 .8

Power to Flow Instrumentation (new 3/4.3.2.6)

Area and Miscellaneous Process Radiation Monitors (new 3/4.3.2.2)

5.4 .10 Seismic Instrumentation (new 3/4.3.2.3) PCRV jurface Temperature Indication (new 3/4.6.2)

5.9 Environmental Surveillance (Superseded by Section 8.0-Amendment 37 $(11 / 23 / 83))$

$5.10 \quad$ Fire Suppression Systems

5.10.1 Three Room Control Complex HVAC System-Added Amendment 18 $(10 / 28 / 7)$

5.10.2 Halon Fire Suppression System-Added Amendment $18(10 / 28 / 77)$ (new 3/4.7.6.3)

5.10.3 Smoke Detectors and Alarm-Added Amendment $18(10 / 28 / 77)$

5.10.4 Fire Barrier Penetration Seal-Added Amendment 18 (10/28/77) (new 3/4.7.7) 

Fixed Water Spray Systems-Addej Amendment 2. (6/6/79) (new 3/4.7.6.1)

5.10.7 Carbon Dioxioe Fire Suppzession System-Added Amendment 22 (8/19/80) (new 3/4.7.6.2)

5.10.8 Fire Hose Stations-Added Amendment 22 (8/19/80) (new 3/4.7.6.4)

5.10.9 Yard Fire Hydrants and Hydrant Hose Houses-Added Amendment 22 $(8 / 19 / 80)$ (new 3/4.7.6.5)

6 Design Features

6.1 Reactor Core (new 5.3, 5.3.1, 5.3.2, 5.3.3, 5.3.5, 5.3.6)

6.2 Reactor Coolani System and Steam Plant System

6.2.1 PCRV (new 5.2.1)

6.2.2 Steam Generator Orifices (new 5.2.2)

6.2.3 Steam Safety Valves (new 5.2.3)

6.3 Site (new 5.1)

$7 \quad$ Administrative Controls (new 6.0)

7.1 Organization, Review and Audit

7.1.1 Organization (new 6.1, 6.2, 6.3, 6.4)

7.1.2 Plant Operations Review Committee (new 6.5, 6.5.1)

7.1.3 Nuclear Facility Safety Committee (new 6.5, 6.5.2)

7.2 Safety Limits (new 6.7)

7.3 Records (new 6.10)

7.4 Procedures (new 6.8, 6.11)

$7.5 \quad$ Reporting Requirements (new 6.9)

7.5.1 Routine Reports (new 6.9.1)

7.5.2 Reportable Occurrences (new 6.6)

7.5.3 Nonroutine Radiological Reports (new 6.9.3)

7.6 Environmental Qualifications (new 6.17)

7.7 Fuel Surveillance Program-Added Amendment 48 (11/25/86) (new 6.16)

8 Radiological Effluents and Environmental Technical Specifications - Added Amendment 37 (11/23/83) (not revised in Tech. Spec. Upgrade) Definitions 
8.I Radiological Effluent Disposal System Radioactive Gaseous Effluents Radioactive Liquid Effluents Reactor Building Sump Effluents Solid Radioactive Wastes Total Dose

8.2 Radiological Environmental Monitoring Program 


\section{APPENDIX A.2}

Final Draft Fort St. Vrain Upgraded Technical Specifications Table of Contents with Cross-Reference to Appendix A to Facility Operating License DPR-34 (Old Technical Specifications) as Amended to Amendment 60 (6/20/88)

\section{INDEX}

1.0 Defir tions (old 2.0)

2.0 Safety and Limiting Safety System Selär.gs

$2.1 \quad$ Safety Limits

2.1.1 Keactor Core Safety Limit (old 3.1)

2.1.2 Reactor Vessel Pressure (old 3.2)

$2.2 \quad$ Limiting Safety System Settings (old 3.3)

2.2.1 Trip Setpoints

Limiting Conditions for Operation and Surveillance Requirements

3/4.0 Applicability (old 4.0/5.0)

3/4.1 Reactivity Control Systems

3/4.1.1 Control Rod Pair Operability (old 4.1.2/5.1.1)

3/4.1.2 Control Rod Pair Position Indication Systenis

3/4.1.2.1 Control Rod Pair Position Indication Systems-Operating (new LCO/old 5.1.1)

3/4.1.2.2 Control Rod Pair Position Indication Systems-St. LCO/old 5.1.1)

3/4.1.3 Shutdow'i Margin (old 4.1.2/5.1.1)

3/4.1.4 Control Rod Worth and Position Requirements

3/4.1.4.1 Control Rod Pair Position and Worth Requirements Operating (old 4.1.3, 4.1.4/5.1.5)

3/4.1.4.2 Control Rod Pair Position Requirements-Shutdown (old 4.1.3, 4.1.4/5.1.5)

3/4.1.5 Reactivity Change with Tempera ire (old 4.1.5/5.1.3)

3/4.1.6 Reserve Shutdown System-System 11 (old 4.1.6/5.1.2)

3/4.1.6.1 Reserve Shutdown System-Operating

3/4.1.6.2 Reserve Shutdown System-Shutdown 
Reactivity Status (old 4.1.8/5.1.4)

$3 / 4.2$

Core Irradiation, Tempera ure and Flow Limits

$3 / 4.21$ Gure Irradiation (old + 1.1/5.1.8)

$3 / 4.2 .2$ Core Inlet Orifice $\mathrm{V}$ alves/Region Outlet Temperature Limits (old 4.1.7/5.1.7)

$3 / 4.2 .3$

Core Inlet Cifice Val : os/Comparison Regions (old 4.1.7/5.1.7)

$3 / 4.2 .4$

$3 / 4.2 .5$

$3 / 4.26$ Core Inlet Orifice $\mathrm{Va}$ : res/Minimum Helium Flow and Core Region Temperature Rise (old 4.1.9 15.1.9)

$3 / 4.3$

Region Constraint Devies (new LCO/old 5.2.' $6,5.2 .27$ )

3/4.3.1

Power-to-Flow Ratio (old 3.1)

$3 / 4.3 .2$

3/4.3.2.1

3/4.3.2.2

3/4.3.2.3

3/4.3.2.4

3/4.3.2.5

3/4.3.2.6

3/4.3.2.7

3/4.3.2.8

Instrumentation

Plant Protective System (old 4.4.1/5.4.1)

Monitoring Instrumentation

Analytical Moisture Monitors (old 4.4.5/5.4.12)

Radiation Monitoring Instrumentation (old 4.4.3/5.4.9)

Seismic Instrumentation (old 4.4.4/5.4.10)

Meteorological Instrumentation (new LCO/old 5.4.16)

Fire Detection and Alarm System! (old 4.10.3/5.4.2)

Chlorine Detection and Alarm System (new LCO/old 5.4.14)

Power-to-Flow Ratio Instrumentation System (new LCO/old 5.4.8)

3/4.3.3

Core Region Outlet Thermocouples (new?)

Three Room Control Complex Temperature Monitoring (old 4.4.2/5.4.7)

3/4.4 Primary Coolant

3/4.4.1 Primary Coolant Loops and Coolant Circulation (new?)

3/4.4.1.1 Primary Coolant Loops and Coolant Circulation- Above 5\% Power (new?)

3/4.4.1.2

Primary Coolant Loops and Coolant Circulation- Below 5\% Power (new?)

3/4.4.2 Primary Coolant Activity (old 4.2.8/5.2.11, 5.26)

3/4.4.3 Frimary Coolant Impurity Levels-High Temperature (old 4.2.10/5.2.12, 5.2.22, 5.2.25)

3/4.4.4 Primary Coolant Impurity Levels-Low Temperature (old 4.2.11/5.2.12)

3/4.5 Safe Shutdown Cooling Systems

3/4.5.1 Helium Circulators (old 4.2.1, 4.2.2, 4.2.19/5.2.7, 5.2.8, 5.2.9, 5.2.23) 
3/4.5.1.1

3/4.5.1.2

$3 / 4.5 .2$

3/4.5.2.1

3/4.5.2.2

$3 / 4.5 .3$

3/4.5.3.1

3/4.5.3.2

$3 / 4.5 .4$

3/4.5.4.1

3/4.5.4.2

$3 / 4.5 .5$

$3 / 4.6$

$3 / 4.6 .1$

3/4.6.1.1

3/4.6.1.2

3/4.6.1.3

$3 / . . .1 .4$

3/4.6.1.5

$3 / 4.6 .2$

3/4.6.2.1

$3 / 4.6 .2 .2$

$3 / 4.6 .3$

$3 / 4.6 .4$

3/4.6.4.1

3/4.6.4.2

$3 / 4.6 .4 .3$

$3 / 4.6 .5$
Helium Circulators-CBCT Above 760 (new LCO/old 5.2.27)

Helium Circulators-CBCT Below 760

Helium Circulator Auxiliaries (new)

Helium Circulator Auxiliaries-CBCT Above 760 (new)

Helium Circulator Auxiliaries-CBCT Below 760 (new)

Steam Generators (old 4.3.1/5.2.7, 5.3.1, 5.3.10, 5.3.11, 5.3.12)

Steam Generators-CECT Above 760

Steam Generators-CBCT Below 760

Emergency Condensate and Emergency Feedwater Headers (old 4.3.4/5.2.7, 5.3.1)

Emergency Condensate and Emergency Feedwater Headers $\mathrm{CBCT}$ Above 760

Emergency Condensate and Emergency Feedwater Headers CBCT Below 760

Safe Shutdown Cooling Water Supply System (old 4.2.6/5.2.10)

PCRV AND CONFINEMENT SYSTEMS

PCRV Pressurization

PCKV Safety Valves (old 4.2.7/5.2.1)

Steam Generator/Circulator Penetration Overpressure Protection (new?)

Interspace Minimum Pressurization (old $42.7 / 5.2 .15$ )

PCRV Closure Leakage (cid 4.2.9/5.2.16)

Steam Generator Interspace Radiation Monitoring (new)

Reactor Plant Cooling Water/PCRV Liner Cooling System (old 4.2.13, 4.2.14/5.4.5, 5.4.11)

Reactor Plant Cooling Water/PCRV Liner Cooling System Operating

Reactor Plant Cooling Water/PCRV Liner Cooling System Shutdown

P-dctor Plant Cooling Water/PCRV Liner Cooling System Temperatures (old 4.2.15/5.4.4)

PCRV Integrity (new LCO/old 5.2.2, 5.2.3, 5.2.4, 5.2.5)

Strisciural Integrity (new?)

Liner (new?)

Penetrations, Wells and Isolation Valves (new?)

Reactor Building Confinement 
3/4.6.5.1

$3 / 4.6 .5 .2$

$3 / 4.6 .5 .3$

3/4.7 Plant and Safety Shutdown Cooling Support Systems

3/4.7.1

$3 / 4.7 .1 .1$

3/4.7.1.2

3/4.7.1.3

3/4.7.1.4

3/4.7.1.5

3/4.7.1.

3/4.7.1.7

$3 / 4.7 .2$

$3 / 4.7 .3$

$3 / 4.7 .4$

3/4.7.4.1

3/4.7.4.2

$3 / 4.7 .5$

$3 / 4.7 .6$

3/4.7.6.1

3/4.7.6.2

$3 / 4.7 .6 .3$

$3 / 4.7 .6 .4$

$3 / 4.7 .6 .5$

$3 / 4.7 .7$

$3 / 4.7 .8$

$3 / 4.7 .9$

$3 / 4.7 .10$

$3 / 4.8$

$3 / 4.8 .1$

3/4.8.1.1

$3 / 4.8 .1 .2$

$3 / 4.8 .2$

3/4.8.2.1 4.5.1/5.5.2)

Turbine Cycle

Boiler Feed Pumps (old 4.3.2/5.2.7)

Steam/Water Dump System (old 4.3.3/5.3.1)

Pressure Relief Valves (new LCO?/old 5.3.3)

Secondary Coolant Activity (old 4.3.8/5.3.7)

Safety Valves-Operating (new LCO/5.3.9)

Safety Valves-Shutdown (new LCO/5.3.9)

Condensate Pumps (new?)

Hydraulic Power System (old 4.3.7/5.3.5)

Instrument Air System (old 4.3.6/5.3.6)

Service Water System

Fire Suppression Systems

Carbon Dioxide Systems (old 4.10.6/5.10.7)

Halon Systems (old 4.10.2/5.10.2)

Fire Hose Stations (old 4.10.7/5.10.8)

Fire Rated Barriers (?) (old 4.10.4/5.10.4) (new)

Snubbers (old 4.3.10/5.3.8)

Auxiliary Electric Power Systems

A.C. Power Sources

D.C. Power Sources
Reactor Building Confinement Integrity (old 4.5.1/5.5.1)

Reactor Building Exhaust System (old 4.5.1/5.5.3)

Reactor Building Overpressure Protection System (old

Service Water System-Operating (old 4.2.4/naw SR?)

Service Water System-Shutdown (old 4.2.4/new SR?)

Primary Coolant Depressurization (old 4.2.18/new SR?)

Spray and/or Sprinkler Systems (old 4.10.5/5.10.6)

Yard Fire Hydrants and Hydrant Hose Houses (old 4.10.8/5.10.9)

Steam Line Rupture Detection/Isolation System (SLRDIS) Valves

Control Room Emergency Ventilation System (new)

A.C. Power Sources-Operating (old 4.6.1/5.6.1)

A.C. Power Sources-Shutdown (old 4.6.1/5.6.1)

D.C. Power Source;-Operating (new LCO/old 5.6.2) 
3/4.8.2.2 D.C. Power Sources-Shutdown (new LCO/old 5.6.2)

3/4.8.3 Onsite Power Distribution

3/4.8.3.1 Onsite Power Distribution-Operating (new)

3/4.8.3.2 Onsite Power Distribution-Shutdown (new)

3/4.8.4 ACM Diesel Generator (old 4.2.17/5.2.20)

3/4.9 Fuel Handling and Storage Systems

3/4.9.1 Fuel Handling and Maintenance in the Reactor (old 4.7.1/new SR?)

3/4.9.2 Instrumentation (new)

3/4.9.3 Fuel Handling Machine (old 4.7.2/5.7.1)

3/4.9.4 Fuel Storage Wells (old 4.7.3/5.7.2)

3/4.9.5 Spent Fuel Shipping Cask (old 4.7.4/new SR?)

3/4.9.6 Communications During Core Alterations (new)

3/4.10 Special Test Exceptions

3/4.10.1 Xenon Stability (old 4.9.3)

Bases

B3/4.0 Applicability

B3/4.1 Reactivity Control Systems

B3/4.2 Core Irradiation, Temperature and Fow Limits

B3/4.3 Instrumentation

B3/4.4 Primary Coolant

B3/4.5 Safe Shutdown Cooling Systems

B3/4.6 PCRV and Confinement Systems

B3/4.7 Plant and Safe Shutdown Cooling Support Systems

B3/4.8 Auxiliary Electric Power Systems

B3/4.9 Fuel Handling and Storage Systems

B3/4.10 Special Test Exceptions

5 Design Features

$5.1 \quad$ Site (old 6.3)

5.2 Reactor Coolant System and Steam Plant System

5.21 Prestressed Concrete Reactor Vessel (PCRV) (old 6.2.1)

5.2.2 Steam Generator Orifices (old 6.2.2)

5.3 Reactor Core (old 6.1)

5.3.1 Reactor Assembly (old 6.1) 
Fuel (old 6.1)

Reload Segment Design (new)

5.3 .5

Reflector (old 6.1)

5.3 .6

Control Rods (old 6.1)

5.3 .7

5.4

Reserve Shutdown System (new)

5.4.1

5.4 .2 Fuel Storage (new)

5.4 .3

5.5

Criticality (new)

Containment (new)

5.6 Component Cyclic or Transient Limit (new)

Neutron Absorber-Heat Sink (new)

6 Administrative Controls (old 7.0)

6.1 Responsibility (old 7.1.1)

6.2 Organization (old 7.1.1)

6.3 Unit Staff Qualifications (old 7.1.1)

6.4 Training (old 7.1.1)

6.5 Review and Audit (old 7.1.2, 7.1.3)

6.5.1 Plant Operations Review Committee (PORC) (old 7.1.2)

6.5.2 Nuclear Facility Safety Committee (NFSC) (old 7.1.3)

6.6 Reportable Events Action (old 7.5.2)

6.7 Safety Limit Violation (old 7.2)

6.8 Procedures and Programs (old 7.4)

6.9 Reporting Requirements (old 7.5)

6.9.1 Routine Reports and Reportable Events (old 7.5.1)

6.9.2 Special Reports (new)

6.9.3 Non-Routine Radiological Reports

6.10 Record Retention (old 7.3)

6.11 Radiation Protection Program (old 7.4)

6.12 High Radiation Area (new)

6.13 Process Control Program (PCP) (new)

6.14 Offsite Dose Calculation Manual (ODCM) (new)

6.15 Major Changes to Liquid, Gaseous, and Solid Radwaste Treatment Systems (new)

6.16 Fuel Surveillance Program (new) 
6.17 Environmental Qualification (old 7.6)

6.18 Inservice Inspection and Testing (ISIT) Program (new)

7.0 Not Used

8.0 Radiological and Environmental (old 8.0) 


\section{APPENDIX A.3}

Fort St. Vrain Amendments to Facility Operating License DPR-34 with Cross-Reference to Previous and Upgraded Fort St. Vrain Technical Specification Sections

\begin{tabular}{|c|c|c|c|c|}
\hline $\begin{array}{l}\text { Lic. } \\
\text { Amnd. } \\
\text { No. }\end{array}$ & $\begin{array}{l}\text { Lic. } \\
\text { Amend. } \\
\text { Issuance } \\
\text { Date } \\
\text { SER affl. }\end{array}$ & $\begin{array}{l}\text { Signed by } \\
\text { (SER by) }\end{array}$ & $\begin{array}{l}\text { Affected } \\
\text { Tech.Spec.Sections } \\
\text { (Old System) }\end{array}$ & $\begin{array}{l}\text { Affected } \\
\text { Tech.Spec.Sections } \\
\text { (New System) }\end{array}$ \\
\hline
\end{tabular}

\begin{tabular}{|c|c|c|c|c|}
\hline 1 & $\begin{array}{l}5 / 17 / 74 \\
\text { NRC/DRL } \\
\text { NRC/DRL }\end{array}$ & $\begin{array}{l}\text { R.P.Denise } \\
\text { (W.C.Gilbert) } \\
\text { (R.A.Clark) }\end{array}$ & $\begin{array}{l}\text { Def. } 2.1 \\
\quad \text { (Del.Amend.16) } \\
\text { LCO 4.2.7 } \\
\text { LCO 4.2.13 } \\
\text { LCO 4.3.7 } \\
\text { LCO 4.3.7 Basis } \\
\text { LCO 4.8.1 } \\
\text { LCO 4.8.2 } \\
\text { LCO 4.8.3 } \\
\text { SR 5.2.3 } \\
\text { SR 5.2.4 } \\
\text { SR 5.4.1 } \\
\text { Table 5.4-2 } \\
\text { AC 7.1.3 } \\
\text { AC 75 } \\
\text { (replaced AC 7.4?) }\end{array}$ & 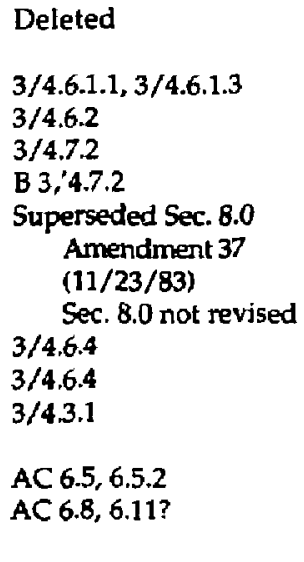 \\
\hline 2 & $\begin{array}{l}6 / 27 / 74 \\
\text { NRC/DRL } \\
\text { NRC/DRL }\end{array}$ & $\begin{array}{l}\text { R.P.Denise } \\
\text { (W.C.Gilbert) } \\
\text { (R.A.Clark) }\end{array}$ & $\begin{array}{l}\text { AC 7.1.1 } \\
\text { AC 7.1.2 } \\
\text { AC 7.1.3 } \\
\text { AC 7.2 } \\
\text { AC 7.3 (Del.Amend.16) } \\
\text { AC 7.6 } \\
\quad \text { (replaced AC 7.5.3?) }\end{array}$ & $\begin{array}{l}\text { AC 6.1, 6.2, 6.3, 6.4 } \\
\text { AC 6.5, 6.5.1 } \\
\text { AC 6.5, 6.5.2 } \\
\text { AC 6.7 } \\
\text { Deleted } \\
\text { AC 6.9.3? }\end{array}$ \\
\hline 3 & $\begin{array}{l}7 / 12 / 74 \\
\text { NRC/DRL } \\
\text { NRC/DRL }\end{array}$ & $\begin{array}{l}\text { R.P.Denise } \\
\text { (W.C.Gilbert) } \\
\text { (R.A.Clark) }\end{array}$ & LCO 4.9.1 & Missing \\
\hline 4 & $\begin{array}{l}11 / 12 / 74 \\
\text { NRC/DRL } \\
\text { NRC/DRL }\end{array}$ & $\begin{array}{l}\text { R.P.Denise } \\
\text { (W.C.Gilbert) } \\
\text { (R.A.Clark) }\end{array}$ & $\begin{array}{l}\text { Def. } 2.20 \text { added } \\
\text { LCO 4.1.3 Basis } \\
\text { LCO 4.1.7 } \\
\text { LCO 4.1.7 Basis } \\
\text { LCO 4.1.9 } \\
\text { LCO 4.1.9 Basis }\end{array}$ & $\begin{array}{l}\text { Def. } 1.13 \\
\text { B 3/4.1.4.1, } \\
\text { B } 3 / 4.1 .4 .2 \\
3 / 4.2 .2,3 / 4.2 .3 \\
\text { B } 3 / 4.2 .2, \text { B } 3 / 4.2 .3 \\
3 / 4.2 .4 \\
\text { B } 3 / 4.2 .4\end{array}$ \\
\hline
\end{tabular}


LCO 4.2.11 Basis

AC 7.1.1

R.P.Denise

NRC/DRL

6

7

8

9

10

11

12

13
NRC/DRL

$1 / 23 / 75$

NRC/DRL

NRC/DRL

4/17/75

NRC/NRR

$12 / 1 / 75$

NRC/NRR

$12 / 29 / 75$

NRC/NRR

$1 / 27 / 76$

NRC/NRR

4/15/76

NRC/NRR

4/26/76

NRC/NRR

(W.C.Gilbert)

(R.A.Clark)

R.P.Denise

(W.C.Gilbert)

(R.A.Clark)

R.A.Clark

(no name)

R.P.Denise

(no name)

R.A.Clark

(no name)

R.A.Clark

(no name)

R.A.Clark

(no name)

R.A.Clark

(no name)

$6 / 18 / 76$

NRC/NRR
R.A.Clark (no name)
SR 5.4.1

Table 5.4-1

Table 5.4-4

LCO 4.4-1

Tabble 4.4-1, Item 11

License Conditions 2.C(2) to 2.C(4)

LCO 4.4.1

Table 4.4-1

LCO 4.3.7

LCO 4.3.7 Basis

B 3/4.7.2

LCO 4.4.1

Table 4.4-1

SR 5.4.1

Table 5.4-1

SR 5.2.17 added

SR 5.2.17 Basis added

SR 5.2.18 added

SR 5.2.18 Basis added

LCO 4.1.8

LCO 4.1.8 Basis

LCO 4.1.9 Basis

LCO 4.2.11

LCO 4.2.11 Basis

LCO 4.3.9

LCO 4.3.9 Basis

LCO 4.4-1

Table 4.4-1 Unit 4

Notes (h) (t)

LCO 4.4.5

LCO 4.4.5 Basis

LCO 4.9.2

LCO 4.0.2 Basis

SR 5.1.4

SR 5.1.4 Basis

SR 5.4.1

Table 5.4-1

SR 5.4.12

SR 5.4.12 Basis

AC 7.6

(replaced 7.5?)
$3 / 4.7 .2$

B 3/4.4.4

AC 6.1, 6.2, 6.3, 6.4

3/4.3.1

3/4.3.1

Not Applicable

3/4.3.1

3/4.2.:

3/4.3.1

Deleted Amend.33

Deleted Amend.33

Missing

Missing

$3 / 4.1 .7$

B $3 / 4.1 .7$

B 3/42.4

$3 / 4,4,4$

B 3/4.4.4

Deleted Amend 21

Deleted Amend 21

3/4.3.1

3/4.3.2.1

B 3/4.3.2.1

Missing

Missing

3/4.1.7

B 3/4.1.7

3/4.3.1

3/4.3.2.1

B 3/4.3.2.1

AC 6.9, 6.9.1, 6.9.3, 6.6 ? 
14 $\begin{array}{ll}\text { 6/18/76 } & \text { R.P.Denise } \\ \text { NRC/NRR? } & \text { (nc name) }\end{array}$

15 $\begin{array}{ll}\text { 6/24/76 } & \text { R.A.Clark } \\ \text { NRC/NRR } & \text { (no name) }\end{array}$

16

$\begin{array}{ll}11 / 17 / 76 & \text { R.P.Denise } \\ \text { NRC/NRR } & \text { (no name) }\end{array}$

17

18
LCO 4.16 added

LCO 4.2.16 Basis added

LCO 4.6.1

SR 5.2.19 added

SR 5.2.19 Basis added

LCO 4.3.10 added

LCO 4.3.10 Basis added

SR. 5.3.8 added

SR 5.3.8 Basis added

Def 2.1 deleted
AC 7.1.1
AC 7.1.2
AC 7.1.3
AC 7.2
AC 7.3
AC 7.4
AC 75.1
AC 75.2

LCO 4.2.2

Def. 2.1

LCO 4.2.8 Basis

LCO 4.2.12

LCO 4.2.12 Basis

LCO 4.17 added

LCO 4.2.17 Basis added

LCO 4.2.18 added

LCO 4.2.18 Basis added

LCO 4.4-1

Table 4.4-3

Notes (t)

LCO 4.4.6 added

LCO 4.4.6 Basis added

LCO 4.10.1 added

LCO 4.10.1 Basis added

LCO 4.10.2 added

LCO 4.10.2 Basis adder

LCO 4.10.3 added

LCO 4.10.3 Basis added

LCO 4.10.4 added

LCO 4.10.4 Basis added

SR 5.2.20 added

SR 5.2.20 Basis added

SR 52.21 added

SR 5.2.21 Basis added

SR 5.4.1

Table 5.4-1, 5.4-2

SR 5.4.13

SR 5.4.13 Basis
Deleted Amenc.21

Deleted Amend 21

3/4.8.1.1, 3/4.8.1.2

Deleted Amend.21

Deleted Amend.21

3/4.7.7

B 3/4.7.7

3/4.7.7

B 3/4.7.7

Deleted

AC 6.1, 6.2, 6.3, 6.4

AC 6.5, 6.5.1

AC $6.5,6.5 .2$

AC 6.7

AC 6.10

AC 6.8, 6.11

AC 6.9.1

AC 6.6

$3 / 4.5 .1$

Def. 1.40

3/4.4.2

Missing

Missing

$3 / 4.8 .4$

B $3 / 4.8 .4$

$3 / 4.7 .5$

B 3/4.7.5

$3 / 4.3 .1$

Missing

Missing

Missing

Missing

3/4.7.6.3

B 3/4.7.6.3

$3 / 4.3 .2 .8$

B 3/4.3.2.8

$3 / 4.7 .7$

B $3 / 4.7 .7$

3/4.8.4

B $3 / 4.8 .4$

3/4.8.4

B $3 / 4.8 .4$

3/4.3.1

Missung

Missing 


\begin{tabular}{|c|c|c|c|c|}
\hline & & & $\begin{array}{l}\text { SR 5.5.3 } \\
\text { SR 5.5.3 Basis } \\
\text { SR 5.6.2 } \\
\text { SR 5.6.2 Basis } \\
\text { SR 5.10.1 added } \\
\text { SR 5.10.1 Basis added } \\
\text { SR 5.10.2 added } \\
\text { SR 5.10.2 Basis added } \\
\text { SR 5.10.3 added } \\
\text { SR 5.10.3 Basis added } \\
\text { SR 5.10.4 added } \\
\text { SR 5.10.4 Basis added } \\
\text { SR 5.10.5 added } \\
\text { SR 5.10.5 Basis added }\end{array}$ & $\begin{array}{l}\text { 3/4.6.5.2 } \\
\text { B 3/4.6.5.2 } \\
\text { 3/4.8.2.1, 3/4.8.2.2 } \\
\text { B 3/4.8.2.1, B 3/4.8.2.2 } \\
\text { Missing } \\
\text { Missing } \\
\text { 3/4.7.6.3 } \\
\text { B 3/4.7.6.3 } \\
\text { Hissing } \\
\text { Missing } \\
\text { 3/4.7.7 } \\
\text { B 3/4.7.7 } \\
\text { Missing } \\
\text { Missing }\end{array}$ \\
\hline 19 & $2 / 23 / 79$ & $\begin{array}{l}\text { T.P.Speis } \\
\text { (none) }\end{array}$ & $\begin{array}{l}\text { License Condition } \\
2 D 3\end{array}$ & Not Applicable \\
\hline 20 & $\begin{array}{l}4 / 20 / 79 \\
\text { NRC/NRR }\end{array}$ & $\begin{array}{l}\text { T.P.Speis } \\
\text { (no name) }\end{array}$ & $\begin{array}{l}\text { SR } 5.2 .22 \text { added } \\
\text { SR } 5.2 .22 \text { Basis added } \\
\text { DF } 6.1\end{array}$ & $\begin{array}{l}3 / 4.4 .3 \\
\text { B } 3 / 4.4 .3 \\
\text { DF 5.3, 5.3.1, 5.3.2 } \\
\quad 5.3 .3,5.3 .5,5.3 .6\end{array}$ \\
\hline 21 & $\begin{array}{l}6 / 6 / 79 \\
\text { NRC/SRRR }\end{array}$ & $\begin{array}{l}\text { W.P.Gammill } \\
\text { (no name) }\end{array}$ & $\begin{array}{l}\text { LCO 4.2.6 Basis } \\
\text { LCO 4.2.16 deleted } \\
\text { LCO 4.2.19 added } \\
\text { LCO 4.2.19 Basis added } \\
\text { LCO 4.3.9 deleted } \\
\text { LCO 4.3.10 } \\
\text { Table 4.3.10-1 } \\
\text { LCO 4.5.1 } \\
\text { LCO 4.5.1 Basis } \\
\\
\text { LCO 4.10.2 Basis } \\
\text { LCO 4.10.3 } \\
\text { Table 4.10-3 added } \\
\text { LCO 4.10.3 Basis } \\
\text { LCO 4.10.5 added } \\
\text { LCO 4.10.5 Basis added } \\
\text { SR 5.1.2 Basis } \\
\text { SR 5.2.7 } \\
\text { SR 5.2.19 deleted } \\
\text { SR 5.2.21 } \\
\text { SR 5.2.23 added } \\
\text { SR 5.2.23 Basis added } \\
\text { SR 5.5.2 } \\
\text { SR 5.10.6 added } \\
\text { SR 5.10.6 Basis added }\end{array}$ & $\begin{array}{l}\text { B 3/4.5.5 } \\
\text { Deleted } \\
\text { 3/4.5.1 } \\
\text { B 3/4.5.1 } \\
\text { Deleted } \\
\text { 3/4.7.1.4 } \\
\text { 3/4.6.5.1, 3/4.6.5.2, } \\
\text { 3/4.6.5.3 } \\
\text { B 3/4.6.5.1. } \\
\text { B } 3 / 4.6 .5 .2, \\
\text { B } 3 / 4.6 .5 .3 \\
\text { B 3/4.7.6.3 } \\
\text { 3/4.3.2.8 } \\
\text { B 3/4.3.2.8 } \\
\text { 3/4.7.6.1 } \\
\text { B 3/4.7.6.1 } \\
\text { B 3/4.1.6 } \\
\text { 3/4.5.1,3/4.5.3 } \\
3 / 4.5 .4,3 / 4.7 .1 .1 \\
\text { Deleted } \\
\text { Missing } \\
\text { 3/4.5.1 } \\
\text { B 3/4.5.1 } \\
\text { 3/4.6.5.3 } \\
3 / 4.7 .6 .1 \\
\text { B 3/4.7.6.1 }\end{array}$ \\
\hline 22 & $\begin{array}{l}8 / 19 / 80 \\
\text { NRC/NRR }\end{array}$ & $\begin{array}{l}\text { R.L.Tedesco } \\
\text { (no name) }\end{array}$ & $\begin{array}{l}\text { LCO 4.2.6 } \\
\text { LCO 4.2.6 Basis }\end{array}$ & $\begin{array}{l}3 / 4.5 .5 \\
\text { B } 3 / 4.5 .5\end{array}$ \\
\hline
\end{tabular}




\begin{tabular}{|c|c|c|c|c|}
\hline & & & $\begin{array}{l}\text { LCO 4.2.17 } \\
\text { LCO 4.2.17 Basis } \\
\text { LCO 4.3.10 } \\
\text { Table 4.3.10-1 } \\
\text { LCO 4.6.1 } \\
\text { LCO 4.10.6 added } \\
\text { LCO 4.10.6 Basis added } \\
\text { LCO 4.10.7 added } \\
\text { LCO 4.10.7 Basis added } \\
\text { LCO 4.10.8 added } \\
\text { LCO 4.10.8 Basis added } \\
\text { SR 5.2.10 } \\
\text { SR 5.2.10 Basis } \\
\text { SR 5.2.24 added } \\
\text { SR 5.2.24 Basis added } \\
\text { SR 5.4.1 } \\
\text { Table 5.4-1 } \\
\text { SR 5.10.3 } \\
\text { SR 5.10.3 Basis } \\
\text { SR 5.10.6 } \\
\text { SR 5.10.6 Basis } \\
\text { SR 5.10.7 added } \\
\text { SR 5.10.7 Basis added } \\
\text { SR 5.10.8 added } \\
\text { SR 5.10.8 Basis added } \\
\text { SR 5.10.9 added } \\
\text { SR 5.10.9 Basis added } \\
\text { DF 6.1 } \\
\text { AC 7.1.1 } \\
\text { AC 7.1.2 } \\
\text { AC 7.1.3 } \\
\text { AC 7.2 } \\
\text { AC: } 1\end{array}$ & $\begin{array}{l}\text { 3/4.8.4 } \\
\text { B 3/4.8.4 } \\
\text { 3/4.7.1.4 } \\
\text { 3/4.8.1.1,3/4.8.1.2 } \\
\text { 3/4.7.6.2 } \\
\text { B 3/4.7.6.2 } \\
\text { 3/4.7.6.4 } \\
\text { B 3/4.7.6.4 } \\
\text { 3/4.7.6.5 } \\
\text { B 3/4.7.6.5 } \\
\text { 3/4.5.5 } \\
\text { B 3/4.5.5 } \\
\text { Missing } \\
\text { Missing } \\
\text { 3/4.3.1 } \\
\text { Missing } \\
\text { Missing } \\
\text { 3/4.7.6.1 } \\
\text { B 3/4.7.6.1 } \\
\text { 3/4.7.6.2 } \\
\text { B 3/4.7.6.2 } \\
\text { 3/4.7.6.4 } \\
\text { B 3/4.7.6.4 } \\
\text { 3/4.7.6.5 } \\
\text { B 3/4.7.6.5 } \\
\text { DF 5.3, 5.3.1, 5.3.2, } \\
5.3 .3,5.3 .5,53.6 \\
\text { AC 6.1,6.2, 6.3, 6.4 } \\
\text { AC 6.5,6.5.1 } \\
\text { AC 6.5,6.5.2 } \\
\text { AC 6.7 } \\
\text { AC 6.8,6.11 }\end{array}$ \\
\hline 23 & $\begin{array}{l}\text { 3/16/81 } \\
\text { NRC/NRR }\end{array}$ & $\begin{array}{l}\text { J.R.Miller } \\
\text { (no name) }\end{array}$ & $\begin{array}{l}\text { SL } 3.1 \\
\text { SL } 3.1 \text { Basis } \\
\text { LCO 4.2.18 } \\
\text { LCO 4.2.18 Basis } \\
\text { LCO 4.4.1 } \\
\text { Tables 4.4-1 to 4.4-4 } \\
\text { Notes } \\
\text { DF 6.1 }\end{array}$ & $\begin{array}{l}\text { SL } 21.1,3 / 4.2 .6 \\
\text { B 2.1.1, B } 3 / 4.2 .6 \\
\text { 3/4.7.5 } \\
\text { B 3/4.7.5 } \\
\text { 3/4.3.1 } \\
\text { DF } 5.3\end{array}$ \\
\hline 23 & $3 / 25 / 81$ & $\begin{array}{l}\text { J.R.Miller } \\
\text { (none) }\end{array}$ & $\begin{array}{l}\text { License Conditions } \\
\text { 2.D.(4) and 2.D.(5) }\end{array}$ & Not Applicable \\
\hline 24 & $\begin{array}{l}11 / 9 / 81 \\
\text { NRC/NRR }\end{array}$ & $\begin{array}{l}\text { G.Kuzmycz } \\
\text { (no name) }\end{array}$ & $\begin{array}{l}L C O 4.2 .7 \\
A C 7.1 .1 \\
A C 7.1 .2 \\
A C 7.1 .3\end{array}$ & $\begin{array}{l}3 / 4.6 .1 .3 \\
\text { AC 6.1, 6.2, 6.3,6.4 } \\
\text { AC 6.5, 6.5.1 } \\
\text { AC } 6.5,6.5 .2\end{array}$ \\
\hline 25 & $\begin{array}{l}3 / 2 / 82 \\
\text { NRC/RIV }\end{array}$ & $\begin{array}{l}\text { G.Kuzmycz } \\
\text { (T.Westermas) }\end{array}$ & $\begin{array}{l}\text { LCO } \$ 3.10 \\
\text { LCO 4.3.10 Basis }\end{array}$ & $\begin{array}{l}3 / 4.7 .7 \\
\text { B 3/4.7.7 }\end{array}$ \\
\hline
\end{tabular}




\begin{tabular}{|c|c|c|c|c|}
\hline & SARC/RIV & (B.Dickerson) & $\begin{array}{l}\text { LCO 4.4.1 } \\
\text { Tables 4.4-1 to 4.4.1 } \\
\text { notes (d), (n) } \\
\text { LCO 4.6.1 } \\
\text { SR 5.4.1 } \\
\text { Table 5.4-1 } \\
\text { Table 5.4-2 } \\
\text { SR 5.5.3 } \\
\text { SR 5.5.3 Basis } \\
\text { AC 7.4 } \\
\text { AC 7.5.1 } \\
\text { AC 7.5.2 } \\
\text { AC 7.5.3 (7.6) }\end{array}$ & $\begin{array}{l}3 / 4.8 .1 .1,3 / 4.8 .1 .2 \\
3 / 4.3 .1 \\
\\
3 / 4.6 .5 .2 \\
\text { B } 3 / 4.6 .5 .2 \\
\text { AC } 6.8,6.11 \\
\text { AC } 6.9 .1 \\
\text { AC } 6.6 \\
\text { AC } 6.17\end{array}$ \\
\hline 26 & $\begin{array}{l}3 / 18 / 82 \\
\text { NRC/NRR }\end{array}$ & $\begin{array}{l}\text { G.Kuzmycz } \\
\text { (G.Kuzmycz) }\end{array}$ & $\begin{array}{l}\text { LCO 4.2.6 Basis } \\
\text { LCO 4.2.7 } \\
\text { LCO 4.2.7 Basis } \\
\text { LCO 4.2.8 } \\
\text { LCO 4.2.9 } \\
\text { LCO 4.2.9 Basis } \\
\text { A.: 7.5.2 }\end{array}$ & $\begin{array}{l}3 / 4.5 .5 \\
3 / 4.6 .1 .3 \\
\text { B 3/4.6.1.3 } \\
3 / 4.4 .2 \\
3 / 4.6 .1 .4 \\
\text { B 3/4.6.1.4 } \\
\text { AC } 6.6\end{array}$ \\
\hline 27 & $8 / 5 / 82$ & $\begin{array}{l}\text { R.A.Clark } \\
\text { (none) }\end{array}$ & $\begin{array}{l}\text { License Condition } \\
\text { 2.D.(3) }\end{array}$ & Not Applicable \\
\hline 28 & $\begin{array}{l}10 / 5 / 82 \\
\text { NRR/CPB } \\
\text { ORNL }\end{array}$ & $\begin{array}{l}\text { G.Kuzmycz } \\
\text { (Y.Hsii) } \\
\text { (S.Ball) }\end{array}$ & $\begin{array}{l}\text { Def. } 2.21 \\
\text { Def. 2.22 } \\
\text { LCO 4.1.6 Basis } \\
\text { LCO 4.1.7 } \\
\text { LCO 4.1.7 Basis } \\
\text { LCO 4.2.2 } \\
\text { LCO 4.2.2 Basis } \\
\text { SR 5.1.7 added } \\
\text { SR 5.1.7 Basis added }\end{array}$ & $\begin{array}{l}\text { Def. } 1.18 \\
\text { Def. } 1.9 \\
\text { B 3/4.1.6 } \\
3 / 4.2 .2,3 / 4.2 .3 \\
\text { B 3/4.2.2, B 2/4.2.3 } \\
3 / 4.5 .1 \\
\text { B } 3 / 4.5 .1 \\
3 / 4.2 .2,3 / 4.2 .3 \\
\text { B 3/4.2.2, B } 3 / 4.2 .3\end{array}$ \\
\hline 29 & $\begin{array}{l}2 / 13 / 82 \\
\text { NRC/RIV }\end{array}$ & $\begin{array}{l}\text { P.C.Wagner } \\
\text { (P.C.Wagner) }\end{array}$ & $\begin{array}{l}\text { SR 5.4.1 } \\
\text { Table 5.4-2 }\end{array}$ & $3 / 4.3 .1$ \\
\hline 30 & $\begin{array}{l}1 / 4 / 83 \\
\text { NRC/NMSS }\end{array}$ & $\begin{array}{l}\text { P.C.Wagner } \\
\text { (nore) }\end{array}$ & $\begin{array}{l}\text { License Condition } \\
\text { 2.D.(3) }\end{array}$ & Not Applicable \\
\hline $\mathbf{c} 30$ & $2 / 1 / 83$ & $\begin{array}{l}\text { G.L.Madsen } \\
\text { (none) }\end{array}$ & $\begin{array}{l}\text { License Condition } \\
\text { 2.D.(4) }\end{array}$ & Not A.pplicable \\
\hline 31 & $\begin{array}{l}1 / 20 / 83 \\
\text { NRC/RIV } \\
\text { NRC/RIV }\end{array}$ & $\begin{array}{l}\text { P.C.Wagner } \\
\text { (T.F.Westerman) } \\
\text { (G.L.Madsen) }\end{array}$ & LCO 4.4.1 & $3 / 4.3 .1$ \\
\hline 32 & $\begin{array}{l}2 / 14 / 83 \\
\text { NRR/EEB }\end{array}$ & $\begin{array}{l}\text { P.C.Wagner } \\
\text { (none) }\end{array}$ & Appendix B & $\begin{array}{l}\text { Appendix B not } \\
\text { revised }\end{array}$ \\
\hline 33 & $\begin{array}{l}3 / 8 / 83 \\
\text { NRC/RIV } \\
\text { LANL }\end{array}$ & $\begin{array}{l}\text { P.C.Wagner } \\
\text { (P.C.Wagner) }\end{array}$ & $\begin{array}{l}\text { Def. } 2.18 \\
\text { Def. } 2.19 \text { or } 2.20 \\
\text { SR } 5.0\end{array}$ & $\begin{array}{l}\text { Def. } 1.38 \\
\text { Def. } 1.4 \text { i or } 1.12 \\
3 / 4.0\end{array}$ \\
\hline
\end{tabular}


SR 5.1.1

SR 5.1.1 Basis

SR5.1.2

SR 5.1.2 Basis

SR 5.1.3

SR 5.1.3 Basis

SR 5.1.4

SR 5.1.4 Basis

SR 5.1.5

SR 5.1.5 Basis

SR 5.1.6

SR 5.1.6 Basis

SR 5.1.7

SR 5.1.7 Basis

SR 5.21

SR 5.2.1 Basis

SR 5.22

SR 5.2.2 Basis

SR 523

SR 5.2.3 Basis

SR 5.2.4

SR 5.2.4 Basis

SR 5.2 .5

SR 5.2.5 R. is

SR 5.2.6

SR 5.2.6 Basis

SR 5.2.7

SR 5.27 Basis

SR 52.8

SR 5.2.8 Basis

SR 5.2.9

SR 5.2.9 Basis

SR 5.210

SR 5.2.10 Basis

SR 5.211

SR 5.2.11 Basis

SR 5.212

SR 5.2.12 Basis

SR 5.213

SR 5.2.13 Basis

SR 5.214

SR 5.2.14 Basis

SR 5.2.15

SR 5.2.15 Basis

SR 5.216

SR 5.2.16 Basis

SR 5.2.17 deleted

SR 5.2.18
3/4.1.1, 3/4.1.2.1, 3/4.1.2.2

B 3/4.1.1, B 3/4.1.2.1, B 3/4.1.2.2

3/4.1.6

B 3/4.1.6

3/4.1.5

B 3/4.1.5

3/4.1.7

B 3/4.1.7

3/4.1.4.1, 3/4.1.4.2

B 3/4.1.4.1, B 3/4.1.4.2

Missing

Missing

$3 / 4.2 .2,3 / 4.2 .3$

B 3/4.2.2, B 3/4.2.3

3/4.6.1.1

B 3/4.6.1.1

$3 / 4.6 .4$

B 3/4.6.4

$3 / 4.6 .4$

B 3/4.6.4

$3 / 4.6 .4$

B 3/4.6.4

$3 / 4.6 .4$

B 3/4.6.4

Missing

Missing

3/4.5.1, 3/4.5.3,

$3 / .5 .4,3 / 4.7 .1 .1$

B 3/4.5.1, B 3/4.5.3,

B $3 / 4.5 .4$, B 3/4.7.1.1

$3 / 4.5 .1$

B 3/4.5.1

3/4.5.1

B 3/4.5.1

$3 / 4.5 .5$

B 3/4.5.5

$3 / 4.4 .2$

B 3/4.4.2

$3,4.4 .3,3 / 4.4 .4$

B 3/4.4.3, B 3/4.4.4

Missing

Missing

Missing

Missing

3/4.6.1.3

B 3/4.6.1.3

3/4.6.1.

B 3/4.6.1.4

Deleted

Missing 


\begin{tabular}{|c|c|c|c|c|}
\hline & & & $\begin{array}{l}\text { SR 5.2.18 Basis } \\
\text { SR 5.2.21 } \\
\text { SR 5.2.21 Basis } \\
\text { SR 5.2.2 } \\
\text { SR 5.2.22 Basis } \\
\text { SR 5.2.23 } \\
\text { SR 5.2.23 Basis } \\
\text { SR 5.2.24 } \\
\text { SR 5.2.24 Basis } \\
\text { SR 5.2.25 added } \\
\text { SR 5.2.25 Basis added } \\
\text { SR 5.2.26 added } \\
\text { SR 5.2.26 Basis added } \\
\text { SR 5.2.27 added } \\
\text { SR 5.2.27 Basis added } \\
\text { SR 5.2.28 added } \\
\text { SR 5.2.28 Basis added } \\
\text { SR 5.3.1 } \\
\text { SR 5.3.1 Basis } \\
\text { SR 5.3.2 } \\
\text { SR 5.3.2 Basis } \\
\text { SR 5.3.3 } \\
\text { SR 5.3.3 Basis } \\
\text { SR 5.3.4 } \\
\text { SR 5.3.4 Basis } \\
\text { SR 5.3.5 } \\
\text { SR 5.3.5 Basis } \\
\text { SR 5.3.6 } \\
\text { SR 5.3.6 Basis } \\
\text { SR 5.3.7 } \\
\text { SR 5.3.7 Basis } \\
\text { SR 53.8 } \\
\text { SR 5.3.8 Basis } \\
\text { SR 5.3.9 } \\
\text { SR 5.3.9 Basis } \\
\text { SR 5.3.10 } \\
\text { SR 5.3.10 Basis } \\
\text { SR 5.3.11 } \\
\text { SR 5.3.11 Basis } \\
\text { SR }\end{array}$ & $\begin{array}{l}\text { Missing } \\
\text { 3/4.8.4 } \\
\text { B 3/4.8.4 } \\
\text { 3/4.4.3 } \\
\text { B 3/4.4.3 } \\
\text { 3/4.5.1 } \\
\text { B 3/4.5.1 } \\
\text { Missing } \\
\text { Missing } \\
\text { 3/4.4.3 } \\
\text { B 3/4.4.3 } \\
\text { 3/4.2.5 } \\
\text { B 3/4.2.5 } \\
\text { 3/4.2.5 } \\
\text { B 3/4.2.5 } \\
\text { Missing } \\
\text { Missing } \\
\text { 3/4.5.3.3/4.5.4, } \\
\text { 3/4.7.1.2 } \\
\text { B 3/4.5.3, B 3/4.5.4. } \\
\text { B 3/4.7.1.2 } \\
\text { Missing } \\
\text { Missing } \\
\text { 3/4.7.1.3 } \\
\text { B 3/4.7.1.3 } \\
\text { Missing } \\
\text { Missing } \\
\text { 3/4.7.2 } \\
\text { B 3/4.7.2 } \\
\text { 3/4.7.3 } \\
\text { B 3/4.7.3 } \\
\text { 3/4.7.1.4 } \\
\text { B 3/4.7.1.4 } \\
\text { 3/4.7.7 } \\
\text { B 3/4.7.7 } \\
\text { Missing } \\
\text { Missing } \\
\text { 3/4.5.3 } \\
\text { B 3/4.5.3 } \\
\text { 3/4.5.3 } \\
\text { B 3/4.5.3 } \\
\text { (n) }\end{array}$ \\
\hline 34 & $\begin{array}{l}3 / 21 / 83 \\
\text { NRC/RIV }\end{array}$ & $\begin{array}{l}\text { P.C.Wagner } \\
\text { (P.C.Wagner) }\end{array}$ & LCO 4.6.1 & $3 / 4.8 .1 .1,3 / 4.8 .1 .2$ \\
\hline 35 & $\begin{array}{l}8 / 10 / 83 \\
\text { NRR/EEB } \\
\text { NRR/EEB } \\
\text { NRR/EEB }\end{array}$ & $\begin{array}{l}\text { P.C.Wagner } \\
\text { (T.D. Cain) } \\
\text { (E.D.Pentecost) } \\
\text { (G.E. Laroche) }\end{array}$ & Appendix B & $\begin{array}{l}\text { Appendix B not } \\
\text { revised }\end{array}$ \\
\hline 36 & $\begin{array}{l}10 / 13 / 83 \\
\text { NRC/RTV } \\
\text { LANL }\end{array}$ & $\begin{array}{l}\text { P.C.Wagner } \\
\text { (P.C.Wagner) }\end{array}$ & $\begin{array}{l}\text { SR 5.1.1 Basis } \\
\text { AC7.1.1 }\end{array}$ & $\begin{array}{c}\text { B } 3 / 4.1 .1 \\
\text { B 3/4.1.2.1, } \\
\text { B 3/4.1.2.2 } \\
\text { AC } 6.1,6.2,6.3,6.4\end{array}$ \\
\hline
\end{tabular}


$\begin{array}{ll}\text { AC 7.1.2 } & \text { AC 6.5,6.5.1 } \\ \text { AC7.1.3 } & \text { AC } 6.5,6.5 .2 \\ \text { AC 7.4 } & \text { AC } 68,6.11\end{array}$

37

11/23/83
NRR/METB
NRR/METB
NRR/METB
NRR/METB
EG\&G Idaho
EG\&G Idaho
EG\&G Idaho
EG\&G Idaho
EG\&G Idaho

P.C.Wagne:

(C.L.Milles)

(C.A.Willis)

(W.W.Meinke)

(F.Congel)

(WSerrano)

(S.W.Duce)

(J.W.Mandler)

(F.B.Simpson)

(T.E.Young)

P.C.Wagner

(D.A.Powers)

(R.E.Ireland)

P.C.Wagner

(D.A.Powers)

RETS 8.0 (supersedes

DF 63

DF 6.3 Basis

AC7.1

AC 73

AC7.4

AC75

AC7.6

SR 5.2.4

SR 5.2.6

SR 5.2.6 Basis

LCO 4.3.10

LCO 4.3.10 Basis

\section{$1 / 3 / 84$ \\ NRC/RTV}

39

40

41

42

43

44

45

46

47
$1 / 25 / 84$
NRC/RIV

NRR: $P$ PB

$3 / 8 / 84$

NRC/RT

6/4/84

NRC/RIV

$6 / 5 / 84$

NRC/RJV
$10 / 26 / 84$

NRC/RIV

$11 / 9 / 84$

NRC/NRR

$1 / 3 / 85$

NRC/RIV?

$3 / 4 / 86$
Tables 4.3.10-1 to

4.3.10-2

SR 538

SR 5.3.8 Basis

DF6.1

P.C.Wagner

(Miichael Tokar)

\section{P.C.Wagner (H.D.Chaney)}

P.C.Wagner

(P.C.Wagner)

P.C.Wagner

(P.C.Wagner)
P.C.Wagner

(P.C.Wagnes)

P.CWagner

(L.Frank)

P.C.Wasner

(P.C.Wagner)

K.L.Heitner
License Condition
2.C.(4)

AC7.12

AC7.13

AC73

AC752

LCO 4.4.1

Tables 4.4.1 to 4.4.4

Notes

LCO 4.4.1 Basis

LCO 4.4 .5

LCO 4.4.5 Basis

SR53.7

SR 5.3.7 Basis

SR 53.12

SR 5.3.12 Basis

LCO 4.10.7

Table 4.10-7

LCO 4.3 .10
RETS 8.0 not revised

5.1

Missing

AC 6.1, 6.2, 6.3, $6.4,6.5$

AC 6.10

AC 6.8, 6.11

AC $6.6,6.9$

AC 6.17

3/4.6.4

Missing

Missing

$3 / 4.7 .10$

B 3/4.7.10

$3 / 4.7 .10$

$3 / 4.7 .10$

$3 / 4.7 .10$

DF 5.3

Not Applicable

AC 6.5, 6.5.1

AC $6.5,6.5 .2$

AC 6.10

AC 6.6

$3 / 4.3 .1$

3/4.3.1

3/4.3.2.1

B 3/4.3.2.1

3/4.7.1.4

B 3/4.7.1.4

3/4.5.3

B 3/4.5.3

3/4.7.6.4

$3 / 4.7 .10$ 


\begin{tabular}{|c|c|c|c|c|}
\hline & NRC/NRR & (K.L.Heitner) & SR 5.3.8 & $3 / 4.7 .10$ \\
\hline 48 & $\begin{array}{l}11 / 25 / 86 \\
\text { NRC/NRR } \\
\text { INEL/EG\&G } \\
\text { INEL/EG\&G } \\
\text { NRC/NRR } \\
\text { NRC/NRR }\end{array}$ & $\begin{array}{l}\text { C.S.Hinson } \\
\text { (E.Lantz) } \\
\text { (E.Gruen) } \\
\text { (C.L.Nalezny) } \\
\text { (K.L.Heitner) } \\
\text { (M.Carrington) }\end{array}$ & AC 7.7 & AC 6.16 \\
\hline 49 & $\begin{array}{l}12 / 15 / 86 \\
\text { NRC/NRR }\end{array}$ & $\begin{array}{l}\text { C.S.Hinson } \\
\text { (E.Lantz) }\end{array}$ & $\begin{array}{l}\text { LCO 4.9.3 Added } \\
\text { LCO 4.9.3 Basis Added }\end{array}$ & $\begin{array}{l}3 / 4.10 .1 \\
\text { В } 3 / 4.10 .1\end{array}$ \\
\hline 50 & $\begin{array}{l}2 / 26 / 87 \\
\text { NRC/NRR } \\
\text { NRC/NRR }\end{array}$ & $\begin{array}{l}\text { K.L.Heitner } \\
\text { (N.Wagner) } \\
\text { (P.Shemanski) }\end{array}$ & $\begin{array}{l}\text { LCO 4.4.1 } \\
\text { Table 4.4-2 to 4.4.3 } \\
\text { Notes (j), (s) } \\
\text { LCO 4.4.1 Basis } \\
\text { SR 5.4.1 } \\
\text { Table 5.4-2 to } 5.4 .3\end{array}$ & $\begin{array}{l}\text { 3/4.3.1 } \\
\text { B 3/4.3.1 } \\
\text { 3/4.3.? }\end{array}$ \\
\hline 51 & $\begin{array}{l}4 / 22 / 87 \\
\text { NRC/NRR }\end{array}$ & $\begin{array}{l}\text { K.L.Heitner } \\
\text { (P.Willing) }\end{array}$ & $\begin{array}{l}\text { SR 5.0 } \\
\text { SR 5.2 } \\
\text { SR 5.2.8 } \\
\text { R 5.2.8 Basis } \\
\text { SR 5.2.9 } \\
\text { SR 5.2.9 Basis } \\
\text { SR 5.2.10 } \\
\text { SR 5.216 } \\
\text { SR 5.2.16 Basis } \\
\text { SR 5.2.21 } \\
\text { SR 5.2.21 Basis } \\
\text { SR 5.2.24 } \\
\text { SR 5.2.24 Basis } \\
\text { SR 5.3.4 } \\
\text { SR 5.3.4 Basis } \\
\text { SR 5.4.5 } \\
\text { SR 5.4.5 Basis }\end{array}$ & $\begin{array}{l}\text { 3/4.0 } \\
\text { Not Applicable } \\
\text { 3/4.5.1 } \\
\text { B 3/4.5.1 } \\
\text { 3/4.5.1 } \\
\text { B 3/4.5.1 } \\
\text { 3/4.5.5 } \\
\text { 3/4.6.1.4 } \\
\text { B 3/4.6.1.4 } \\
3.4 .8 .4 \\
\text { B 3/4.8.4 } \\
\text { Missing } \\
\text { Missing } \\
\text { Missing } \\
\text { Missing } \\
\text { 3/4.6.2 } \\
\text { B 3/4.6.2 }\end{array}$ \\
\hline 52 & $\begin{array}{l}4 / 3 / 87 \\
\text { NRC/NRR }\end{array}$ & $\begin{array}{l}\text { K.L.Heitner } \\
\text { (K.L.Heitner) }\end{array}$ & $\begin{array}{l}\text { LCO 4.4.1 } \\
\text { Table 4.4-3 }\end{array}$ & $3 / 4.3 .1$ \\
\hline 53 & $\begin{array}{l}5 / 5 / 87 \\
\text { NRC/NRR }\end{array}$ & $\begin{array}{l}\text { K.L.Heitner } \\
\text { (D.Scalelti) }\end{array}$ & $\begin{array}{l}\text { LCO } 4.10 .7 \\
\text { Table 4.10-7 }\end{array}$ & $3 / 4.7 .6 .4$ \\
\hline 54 & $\begin{array}{l}5 / 20 / 87 \\
\text { NRC/NRR }\end{array}$ & $\begin{array}{l}\text { K.L.Heitner } \\
\text { (I.Ahmed) }\end{array}$ & $\begin{array}{l}\text { SR 5.6.1 } \\
\text { SR 5.6.1 Basis }\end{array}$ & $\begin{array}{l}3 / 4.8 .1 \\
\text { B } 3 / 4.8 .1\end{array}$ \\
\hline 55 & $\begin{array}{l}6 / 29 / 87 \\
\text { NRC/NRR }\end{array}$ & $\begin{array}{l}\text { K.L.Heitner } \\
\text { (K.L.Heitner) }\end{array}$ & $\begin{array}{l}\text { LCO 4.3.1 } \\
\text { LCO 4.3.1 Basis } \\
\text { SR 53.10 } \\
\text { SR 5.3.10 Basis }\end{array}$ & $\begin{array}{l}3 / 4.5 .3 \\
\text { B } 3 / 4.5 .3 \\
3 / 4.5 .3 \\
\text { B } 3 / 4.5 .3\end{array}$ \\
\hline 56 & $\begin{array}{l}7 / 13 / 87 \\
\text { NRR/PEB }\end{array}$ & $\begin{array}{l}\text { K.L.Heitner } \\
\text { (F.Allenspach) }\end{array}$ & $\begin{array}{l}\text { AC7.1.1 } \\
A C 7.12 \\
A C 7.13\end{array}$ & $\begin{array}{l}A C 6.1,6.2,6.3,6.4 \\
A C 6.5,6.5 .1 \\
A C 6.5,6.5 .2\end{array}$ \\
\hline
\end{tabular}


AC7.4

57

11/23/87 K.L.Heitner

NRR/SRXB

(E.Lantz)

58

59

60

ORNL

K.L.Heitner

(R.Lasky)

NRR/ICSB

4/ 7/88

NRR/EMEB

K.L.Heilner

(M.Hartzman)

K.L.Heitner
Def. 2.23 added

Def, 2.24 added

LCO4.0.1

LCO4.02

1004.03

LCO 4.0.4

Fig- 4.0-1

Fig. 4.0-2

LCO 4.0.4 Basis

LCO4.1.9

Table 4.1.9-1,

Figs. 4.1.9-1 to

4.1.9.5

LCO.4.1.9 Basis

SR 5.1.8 added

SR 5.1.8 Basis added

(R.Lasky)
SR 5.4.1

Tables 5.4.1 to 5.4.4

LCO4.3.10

Table 4.3.10-1 deleted

SR 5.3 .8

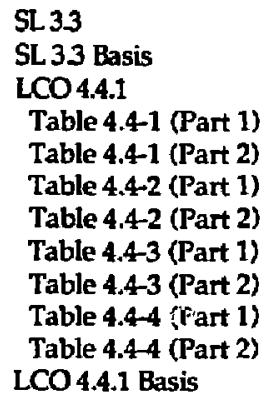

2.2.1

B 2.2.1

3/4.3.1

Table 3.3.1-1 (Pt.1)

Table 3.3.1-1 (Pt.2)

Table 3.3.1-2 (Pt.1)

Table 3.3.1-2 (Pt.2)

Table 3.3.1-3 (Pt.1)

Table 3.3.1-3 (Pt.2)

Table 3.3.1-4 (Pt.1)

Table 3.3.1-4 (Pt.2)

S 3/4.3.1

$$
\begin{aligned}
& \mathrm{B}=\text { Bases } \\
& \text { Def. }=\text { Definition } \\
& \mathrm{SL}=\text { Safety Limit } \\
& \mathrm{LCO}=\text { Limiting Condition for Operation } \\
& \mathrm{SR}=\text { Surveillance Requirement } \\
& \mathrm{DF}=\text { Design Feature } \\
& \mathrm{AC}=\text { Administrative Control }
\end{aligned}
$$




\section{APPENDIX A.4}

Acronyms Used in Technical Evaluation Report of Fort St. Vrain Final Draft Upgraded Technical Specifications

\begin{tabular}{|c|c|}
\hline $\mathrm{ACM}$ & Alternate Cooling Method \\
\hline ASME & American Society of Mechanical Engineers \\
\hline CBCT & Calculated Bulk Core Temperature \\
\hline EDG & Emergency Diesel Generator \\
\hline EFPD & Effective Full Power Days \\
\hline FSAR & Final Safety Analysis Report \\
\hline FSV & Fort St. Vrain \\
\hline GDC & General Design Criteria \\
\hline HTGR & High Temperature Gas-Cooled Reactor \\
\hline HVAC & Heating, Ventilation and Air Conditioning \\
\hline IACM & Interim Alternate Cooling Method \\
\hline LCO & Limiting Condition for Operation \\
\hline LLNL & Lawrence Livermore National Laboratory \\
\hline LWR & Light Water Reactor \\
\hline MPC & Maximum Permissible Concentrations \\
\hline$M P T$ & Main Power Transformer \\
\hline NFSC & Nuclear Facility Safety Committee \\
\hline NRC & Nuclear Regulatory Commission \\
\hline NRR & NRC Office of Nuclear Reactor Regulation \\
\hline ORN & Oak Ridge National Laboratory \\
\hline
\end{tabular}


PCRV

PPS

PSC

PWR

RAT

RSU

SDG

SER

SR

$T / S$

TSUP

UAT

UT/S

wsts
Prestressed Concrete Reactor Vessel

Plant Protection System

Public Service of Colorado

Pressurized Water Reactor

Reserve Auxiliary Transformer

Reserve Shutdown Units

Standby Diesel Generators

Safety Evaluation Report

Surveillance Requirement

Technical Specifications

Technical Specifications Upgrade Program

Unit Auxiliary Transformer

Upgraded Technical Specification

Westinghouse Standard Technical Specifications 